\title{
Ground-Water and Aquifer-System-Compaction Data From the Lorenzi Site, Las Vegas, Nevada, 1994-99
}

By Michael T. Pavelko

U.S. GEOLOGICAL SURVEY

Open-File Report 00-362

Prepared in cooperation with the NEVADA DEPARTMENT OF CONSERVATION AND NATURAL RESOURCES, DIVISION OF WATER RESOURCES and LAS VEGAS VALLEY WATER DISTRICT

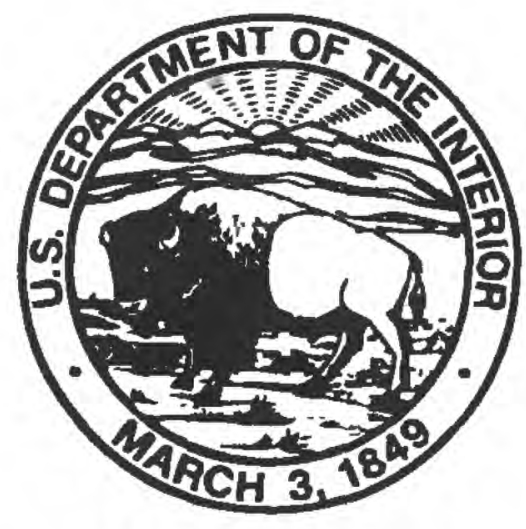

Carson City, Nevada 2000 


\title{
U.S. DEPARTMENT OF THE INTERIOR BRUCE BABBITT, Secretary
}

\author{
U.S. GEOLOGICAL SURVEY \\ CHARLES G. GROAT, Director
}

Any use of trade, product, or firm names in this publication is for descriptive purposes only and does not imply endorsement by the U.S. Government

For additional information contact:

\section{District Chief}

U.S. Geological Survey 333 West Nye Lane, Room 203

Carson City, NV 89706-0866

email: GS-W-NVpublic-info@usgs.gov

http://nevada.usgs.gov
Copies of this report can be purchased from:

U.S. Geological Survey Information Services

Building 810

Box 25286, Federal Center

Denver, CO 80225-0286 


\section{CONTENTS}

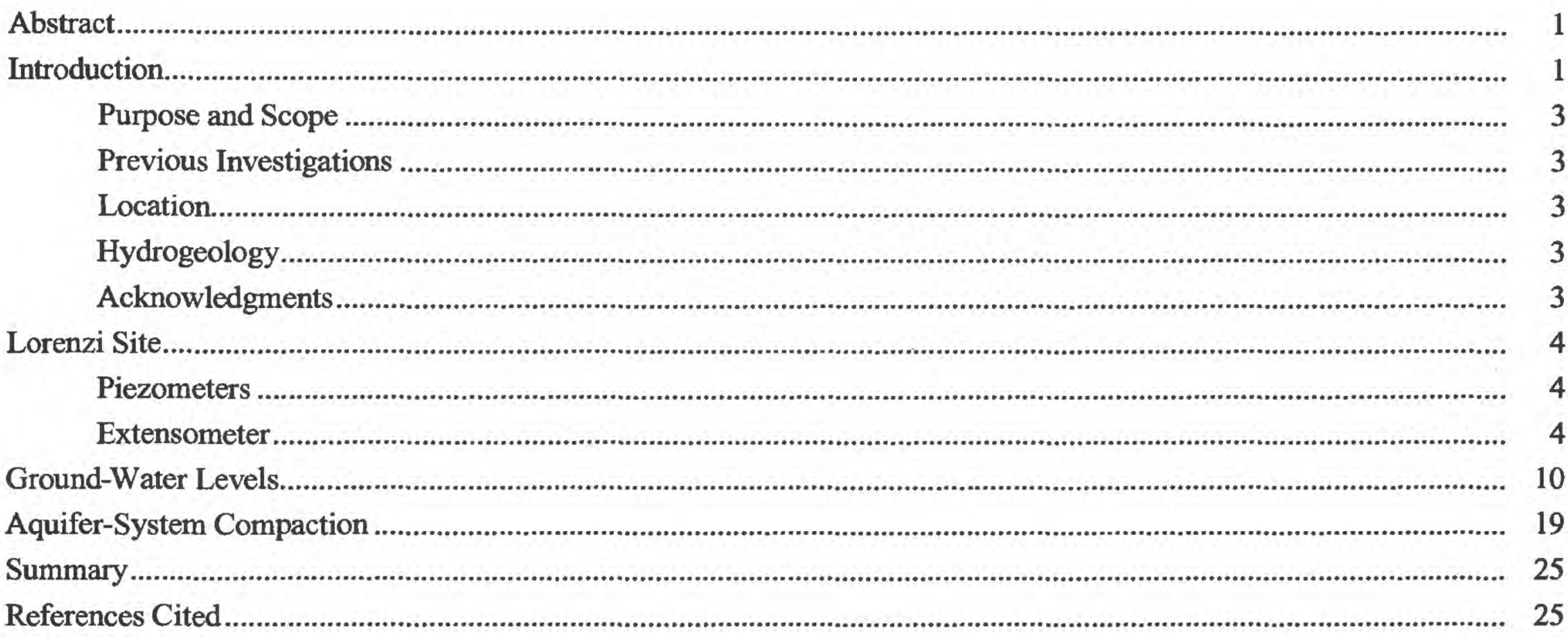

\section{FIGURES}

1. Map showing the location of the Lorenzi site and nearby Las Vegas Valley Water District (LVVWD) wells, Las Vegas, Nevada.

2. Diagram showing geophysical logs and interpreted lithology from extensometer USGS-EXT1 at the Lorenzi site.

3. Photograph showing the Lorenzi site

4. Schematic showing below-ground construction of the extensometer and piezometers at the Lorenzi site ............... 8

5. Schematics and photograph showing above-ground construction of the extensometer at the Lorenzi site .............. 9

6-8. Graphs showing for the Lorenzi site:

6. Ground-water levels and aquifer-system compaction, November 16, 1994-December 31, 1999 ................. 16

7. Daily ground-water pumpage, ground-water levels, and aquifer-system compaction, during a season of diurnal pumping, May 30-October 7, 1999.

8. Hourly ground-water pumpage and ground-water levels, during a period of diurnal pumping, July 17-26, 1999

9-13. Graphs showing ground-water levels and aquifer-system compaction for the Lorenzi site, during:

9. A season of near-continuous pumping, April 10-October 27, 1995.

10. A period of near-continuous pumping, July 17-26, 1995.

11. A season of diurnal pumping, July 17-26, 1999.

12. A season of artificial recharge, September 27, 1998-June 3, 1999

13. A period of artificial recharge, January 20-29, 1999.

\section{TABLES}

1. Well-construction data for piezometers and the extensometer at the Lorenzi site, Las Vegas, Nevada....................

2. Periodic depth-to-water measurements in piezometers at the Lorenzi site, 1995-99 ............................................ 11

3. Summary of continual depth-to-water measurements in piezometers at the Lorenzi site, 1994-99........................ 14 


\section{CONVERSION FACTORS AND VERTICAL DATUM}

\begin{tabular}{rll}
\hline Multiply & By & To obtaln \\
\hline inch (in.) & 2.54 & centimeter \\
foot (ft) & 0.3048 & meter \\
& millimeter \\
mile (mi) & 104.8 & kilometer \\
square mile $\left(\mathrm{mi}^{2}\right)$ & 2.590 & square kilometer \\
pound (lb) & 0.4536 & kilogram \\
pound per square inch (lb/in $\left.{ }^{2}\right)$ & 6,895 & pascal \\
millibar (mbar) & 100.0 & pascal \\
\hline
\end{tabular}

Temperature: Degrees Fahrenheit $\left({ }^{\circ} \mathrm{F}\right)$ may be converted to degrees Celsius $\left({ }^{\circ} \mathrm{C}\right)$ by the following equation: ${ }^{\circ} \mathrm{C}=5 / 9\left({ }^{\circ} \mathrm{F}-32\right)$.

Sea level: In this report, "sea level" refers to the National Geodetic Vertical Datum of 1929 (NGVD of 1929, formerly called "Sea-Level Datum of 1929"), which is derived from a general adjustment of the first-order leveling networks of the United States and Canada. 


\title{
Ground-Water and Aquifer-System-Compaction Data From the Lorenzi Site, Las Vegas, Nevada, 1994-99
}

\author{
By Michael T. Pavelko
}

\section{ABSTRACT}

The U.S. Geological Survey, in cooperation with the Las Vegas Valley Water District (LVVWD) and the Nevada Department of Conservation and Natural Resources, Division of Water Resources, is investigating land subsidence in Las Vegas, Nevada. As part of this study, ground-water levels and aquifer-system compaction are monitored at the Lorenzi site in northwest Las Vegas. The site is near 14 LVVWD wells used to pump ground water during periods of high water demand (May through September) and to provide artificial recharge during the remainder of the year. The data are used to determine relations between water-level fluctuations and aquifer-system compaction, to help calibrate a numerical flow model being developed to simulate aquifer-system compaction at the site, and to help estimate hydraulic properties.

Ground-water-level and aquifer-system-compaction data were collected at the Lorenzi site from November 1994 through December 1999. Water-level data were collected from three nested piezometers in three major aquifers at the site. Ground-water-pumpage and artificial-recharge data are compiled for 14 LVVWD wells near the site. Aquifer-system-compaction data were collected from a borehole extensometer that measures compaction from 12 to 800 feet below land surface.

Data indicate ground-water levels and aquifersystem compaction rates fluctuated cyclically in a manner consistent with alternating seasons of ground-water pumpage and artificial recharge in nearby LVVWD wells. Declining water levels and increased compaction rates correspond to periods of ground-water pumpage. Rising water levels and reduced rates of compaction (or temporary aquifer-system expansion) correspond to periods of artificial recharge. From November 1994 through December 1999, a maximum of 1.0327 inches of aquifer-system compaction occurred at the Lorenzi site. The average annual aquifer-system compaction was about 0.2000 inch.

\section{INTRODUCTION}

Decades of ground-water overdraft in Las Vegas Valley, Nevada (fig. 1), have caused aquifer-system compaction and land-surface subsidence. Since the 1930 's, local ground-water levels have declined by as much as $300 \mathrm{ft}$ and the land surface has subsided by more than $5 \mathrm{ft}$ in some parts of the valley (Bell and Price, 1993). Land subsidence and associated earth fissuring have caused damage to engineered structures, including buildings, roads, and pipelines (Bell, 1981; Bell and Price, 1993).

Beginning in the 1970's, additional water from the Colorado River was imported into the Las Vegas Valley to meet increased municipal water-supply demands. Ground-water pumpage was reduced and local ground-water levels began to recover. In 1987, LVVWD implemented an artificial-recharge program to store surplus Colorado River water temporarily in the aquifer system and slow the rate of aquifer-system compaction by raising ground-water levels. Despite some water-level recovery, land subsidence in Las Vegas Valley continues. One study has shown that residual compaction from past pumping will continue for years or maybe decades (Waichler and Cochran, 1993).

The U.S. Geological Survey (USGS), in cooperation with the LVVWD and the Nevada Department of Conservation and Natural Resources, Division of Water Resources, has developed a study to investigate land subsidence in Las Vegas Valley. As part of this study, ground-water levels and aquifer-system compaction are measured at the Lorenzi site in northwest Las Vegas (fig. 1). The data are being used to establish relations between water-level fluctuations and aquifersystem compaction, to help calibrate a numerical model that simulates aquifer-system compaction at the site, and to help estimate hydraulic properties. The term compaction, used in this report, refers to both aquifersystem compaction and expansion. 


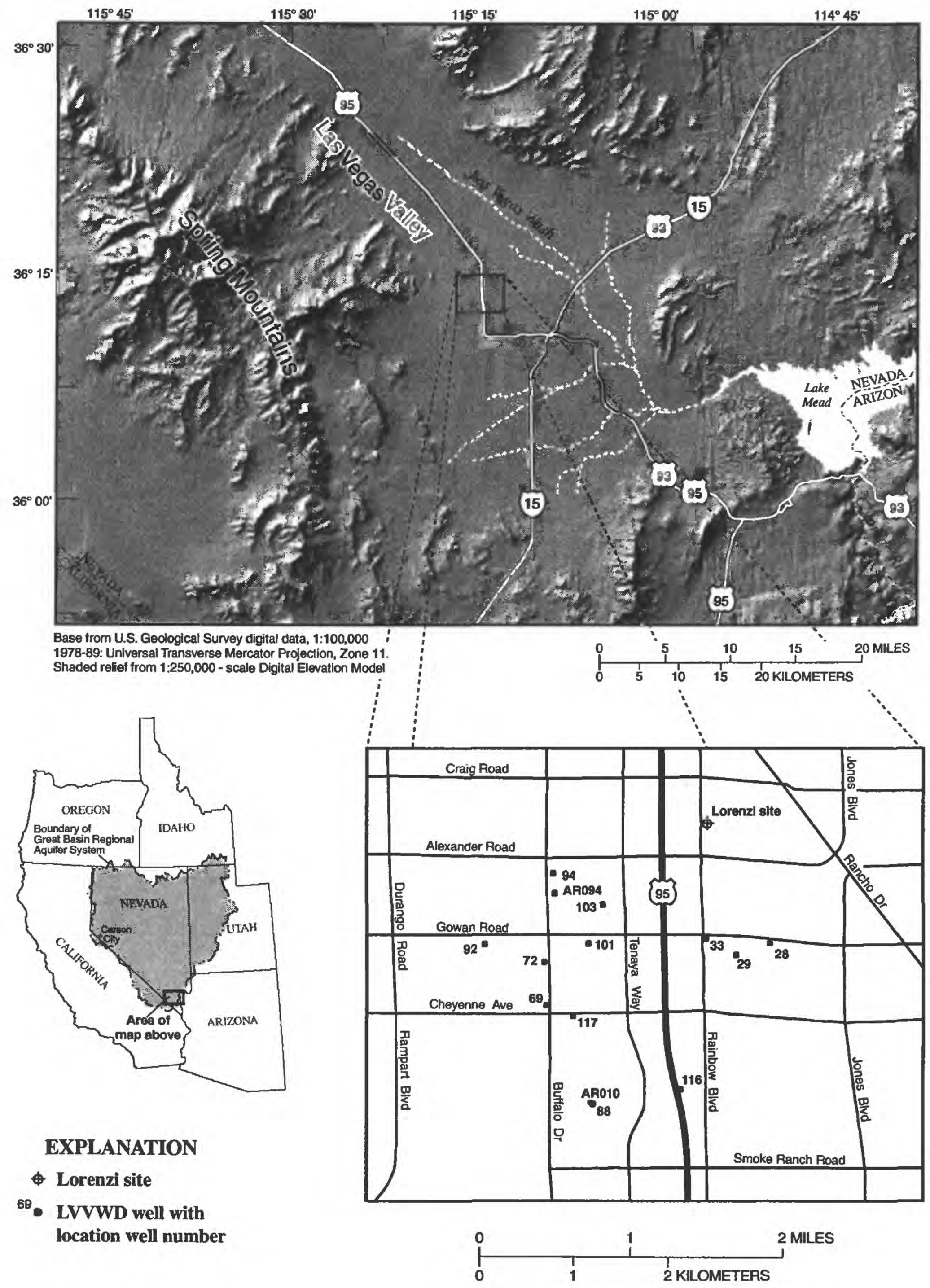

Figure 1. Location of the Lorenzi site and nearby Las Vegas Valley Water District (LVVWD) wells, Las Vegas, Nevada. 


\section{Purpose and Scope}

This report presents data collected at the Lorenzi site from November 1994 through December 1999 and describes data-collection techniques. This report also presents relations between water-level fluctuations and aquifer-system compaction at the Lorenzi site. This report includes well-construction data for the piezometers and extensometer, geophysical logs from the extensometer borehole, ground-water levels measured in three nested piezometers, and aquifer-system compaction data measured in a borehole extensometer. Ground-water pumpage data for 12 municipal production wells near the Lorenzi site (LVVWD wells 28, 29, $33,69,72,88,92,94,101,103,116$, and 117; fig. 1) are presented for the period from May through September 1999.

\section{Previous Investigations}

Water-resources investigations that deal primarily with land subsidence and related issues in Las Vegas Valley include Malmberg (1964), Mindling (1965; 1971), Bell (1981), Bell and Price (1993), and Pavelko and others (1999). General water-resources investigations that include information about land subsidence in Las Vegas Valley include Maxey and Jameson (1948), Domenico and others (1964), Malmberg (1965), Plume (1989), and Morgan and Dettinger (1996). Domenico and others (1966) examined geologic controls of land subsidence in Las Vegas Valley. Harrill (1976) examined ground-water storage depletion in Las Vegas Valley. Carpenter (1915) examined the general hydrology of Las Vegas Valley. Amelung and others (1999) and Hoffmann (Stanford University, written commun., 1999) examined land subsidence in Las Vegas Valley using interferometric synthetic aperture radar data. Sneed and others (2000) presented preliminary model results for a one-dimensional (vertical), numerical ground-water-flow model of land subsidence for the Lorenzi site.

\section{Location}

Las Vegas Valley is in southern Nevada and in the southern part of the Great Basin Regional Aquifer System (fig. 1). The valley is about $1,600 \mathrm{mi}^{2}$, with altitudes ranging from about $1,600 \mathrm{ft}$ above sea level on the valley floor to about $12,000 \mathrm{ft}$ above sea level in the Spring Mountains. The northwest-trending valley is bounded on all sides by various mountains. The Las Vegas Wash drains the valley to the east and flows into Lake Mead. Average annual precipitation ranges from about $4 \mathrm{in}$. on the valley floor to more than $20 \mathrm{in}$. on the surrounding mountains. Temperatures on the valley floor range from below freezing to over $115^{\circ} \mathrm{F}$.

\section{Hydrogeology}

The Las Vegas Valley is a structural trough bounded below and on the sides by carbonate, siliciclastic, and igneous bedrock. Alluvial deposits as thick as $5,000 \mathrm{ft}$ overlay the bedrock. The alluvial deposits comprise a stratigraphically complex system of aquifers and aquitards. Major aquifers consist mainly of thick deposits of sand and gravel; major aquitards consist mainly of thick deposits of low permeability silt and clay. The aquifer system also contains numerous thin, laterally discontinuous interbeds of low permeability silt and clay that may be interfingered.

In the central and eastern parts of the valley, the upper 100 to $300 \mathrm{ft}$ of sediment comprise a zone of near-surface aquifers consisting of laterally extensive, complexly interbedded clay, silt, sand, and gravel (Maxey and Jameson, 1948; Morgan and Dettinger, 1996). Caliche and low permeability zones within the near-surface aquifer partially confine underlying developed aquifers (Morgan and Dettinger, 1996). In the western part of the valley, the zone of near-surface aquifers is absent. Shallow layers of caliche and thick clay and silt layers partially confine aquifers in the west. In Las Vegas Valley, most ground water is pumped from aquifers that consist mostly of sand and gravel deposits separated by variably thick clay and silt layers.

\section{Acknowledgments}

The author would like to thank the people that provided help in the preparation of this report. Erin Cole of the LVVWD provided information, insights, and data about municipal production wells, groundwater withdrawals, and artificial recharge in Las Vegas Valley. Randell J. Laczniak, USGS, Las Vegas, Nevada; Devin L. Galloway, USGS, Sacramento, California; and Francis S. Riley, USGS, Menlo Park, California provided technical and field assistance. The Nevada Power Company allowed use of land at their Lorenzi substation for operating the monitoring site. 


\section{LORENZI SITE}

The Lorenzi site is in northwestern Las Vegas, Nevada, at the Nevada Power Company's Lorenzi substation, on Rainbow Boulevard between Craig and Alexander Roads (fig. 1). This site was selected after reviewing previous studies that indicate the surrounding area has a higher rate of land subsidence than other areas of Las Vegas Valley (Harrill, 1976; Bell, 1981). The site is within a 2-mi radius of $14 \mathrm{LVVWD}$ wells used to pump ground water from about May through September and/or to provide artificial recharge from about October through May. Of these 14 wells, LVVWD wells 69, 88, 92, 94, 101, 103, 116, and 117 are used to pump ground water, LVVWD wells AR010 and AR094 are used to artificially recharge the aquifer system, and LVVWD wells $28,29,33$, and 72 are used to pump and artificially recharge the aquifer system.

The Lorenzi site, established in 1994, consists of three nested piezometers (USGS-PZD, USGS-PZM, and USGS-PZS) and a vertical borehole extensometer (USGS-EXT1; table 1). Geophysical (fig. 2) and lithologic logs from the extensometer borehole indicate the presence of three major aquifers and three major aquitards at the site (Paillet and Crowder, 1996). Geophysical logs indicate the aquifer depths range from 255 to 308,420 to 500 , and 605 to $800 \mathrm{ft}$ below land surface (F.L. Paillet, U.S. Geological Survey, written commun., 1994). The lithologic log indicates that thin layers of caliche are present from land surface to $70 \mathrm{ft}$ below land surface, the major aquifers consist of sand and gravel with interbedded layers of silt and clay, and the major aquitards consist of silt and clay (T.J. Burbey, U.S. Geological Survey, written commun., 1994).

The nested piezometers are protected by a steeland-wood housing; the extensometer is housed in a wooden shed approximately $20 \mathrm{ft}$ from the piezometers (fig. 3). Additional equipment housed in the shed includes a barometer, air-temperature probes, data logger, data-storage device, electronics-panel box, and all necessary electronic components.

Barometric pressure is measured inside the shed. Air temperature is measured inside the shed, inside the electronics-panel box, and $10 \mathrm{ft}$ below land surface in the extensometer borehole. The electronics-panel box encases a data logger and a data-storage device. A rechargeable battery and a solar panel provide power to the data-collection system. A voltage regulator conditions voltage from the solar panel to the battery.
Barometric-pressure, temperature, and battery-voltage data are not presented, but are available upon request from the USGS Las Vegas office.

\section{Piezometers}

The three nested piezometers at the Lorenzi site were installed in May 1994. A 16-in. diameter borehole was drilled to a depth of $52 \mathrm{ft}$ below land surface and a 12.25-in. diameter borehole was drilled from 52 to 703 $\mathrm{ft}$ below land surface. A 12-in. diameter steel conductor casing extends from land surface to $52 \mathrm{ft}$ below land surface. USGS-PZS and USGS-PZM are constructed of 2-in. diameter polyvinyl chloride (PVC) casing and screen; USGS-PZD is constructed of 2.25-in. outer diameter, acrylonitrile butadiene styrene (ABS) casing and screen. Each piezometer is screened at a depth interval corresponding to an aquifer identified with borehole-geophysical logs. USGS-PZS is screened from 300 to $310 \mathrm{ft}$ below land surface; USGS-PZM is screened from 447 to $457 \mathrm{ft}$ below land surface; and USGS-PZD is screened from 677 to $687 \mathrm{ft}$ below land surface. A gravel pack is in the annular space adjacent to each screened interval. Neat cement in the remaining annular space isolates each screened interval from other zones of the aquifer system. Construction data for each piezometer are listed in table 1 and shown in figure 4.

\section{Extensometer}

The borehole extensometer at the Lorenzi site (USGS-EXT1) is a counterbalanced double-pipe extensometer (figs. 4 and 5) that measures vertical aquifer-system compaction. The extensometer borehole was installed in April 1994 by drilling a 16-in. diameter borehole to a depth of $52 \mathrm{ft}$ below land surface and a 10.75-in. diameter hole from 52 to $800 \mathrm{ft}$ below land surface. Vertical-deviation logs collected at the time of drilling indicate that the borehole deviates about 1.75 degrees from vertical. A 12-in. diameter steel conductor casing extends from land surface to $52 \mathrm{ft}$ below land surface and a 6-in. diameter steel "telescoping" casing, extending the length of the hole, is anchored within a cement plug at the bottom of the borehole. A telescoping casing includes slip joints that allow the casing string to lengthen and shorten as vertical deformation occurs. Inclusion of slip joints in an extensometer casing string minimizes frictional stress between the casing and adjacent sediments and 


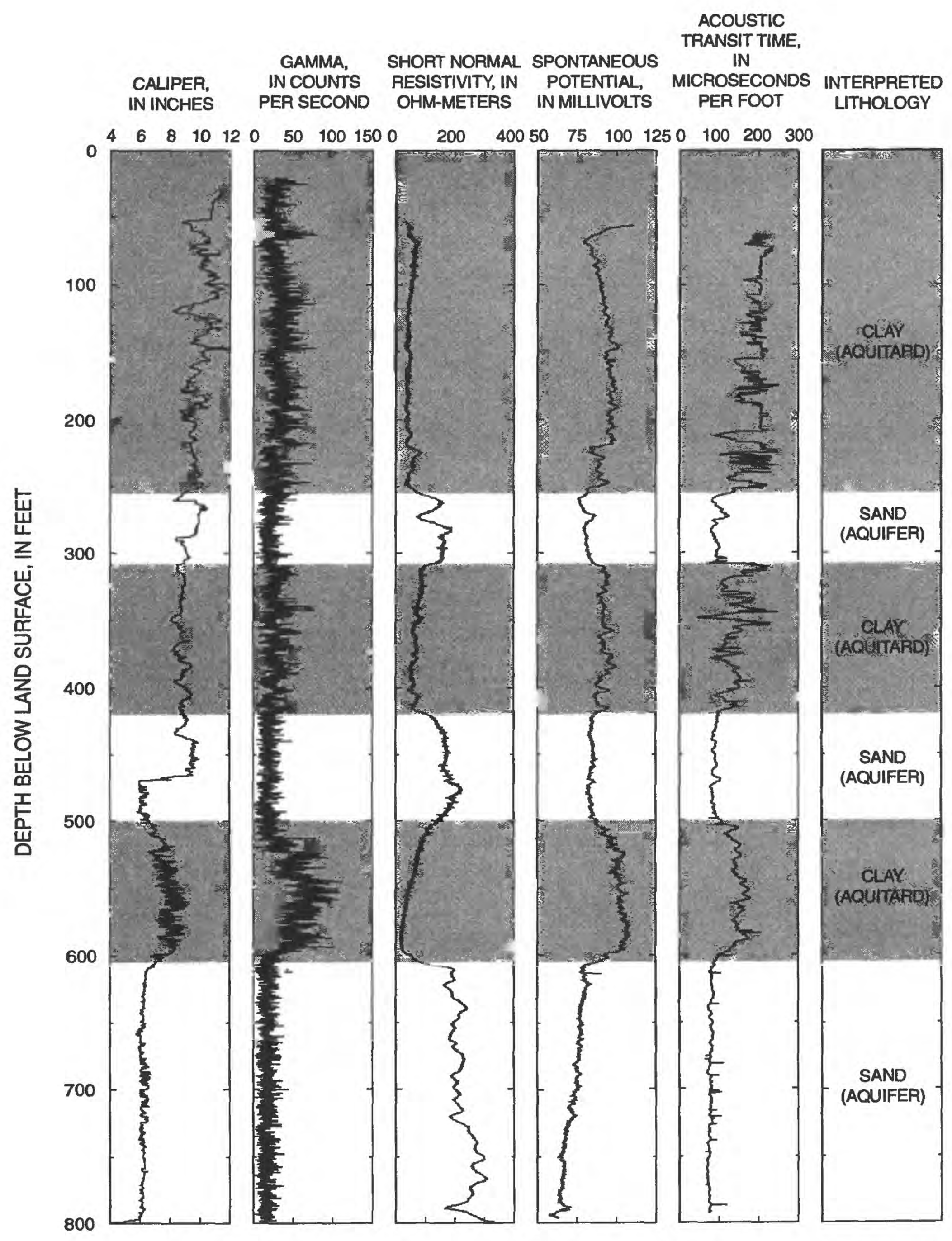

Figure 2. Geophysical logs and interpreted lithology from extensometer USGS-EXT1 at the Lorenzi site, Las Vegas, Nevada. 


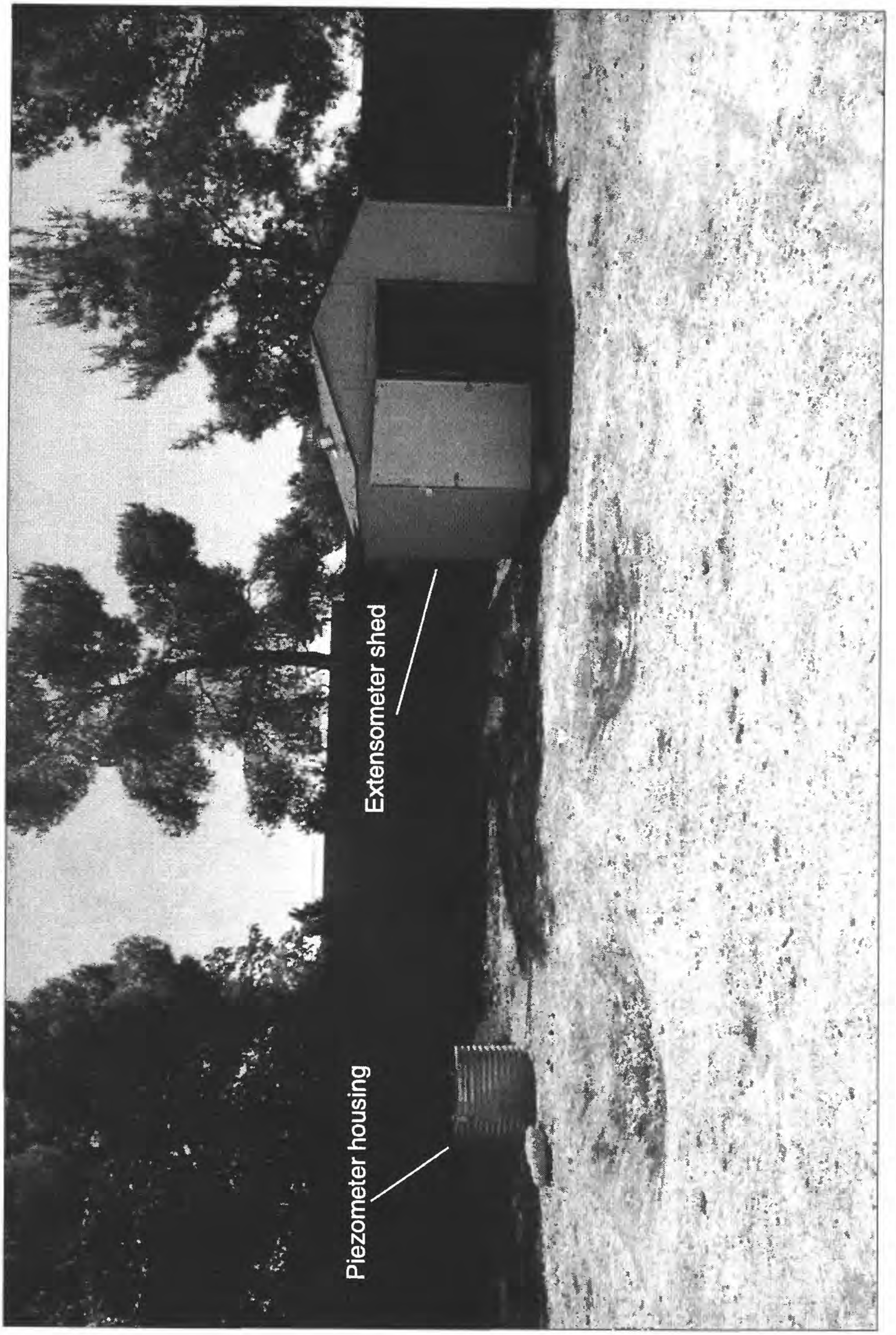

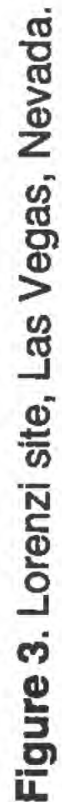


Table 1. Well-construction data for piezometers and the extensometer at the Lorenzi site, Las Vegas, Nevada

\begin{tabular}{|c|c|c|c|c|c|c|}
\hline \multirow[t]{2}{*}{ Weil name } & \multirow{2}{*}{$\begin{array}{c}\text { USGS site } \\
\text { identification } \\
\text { number }\end{array}$} & \multirow[t]{2}{*}{$\begin{array}{l}\text { Date drilled } \\
\text { (1994) }\end{array}$} & Depth & $\begin{array}{l}\text { Casing } \\
\text { depth }\end{array}$ & $\begin{array}{l}\text { Top of } \\
\text { screened } \\
\text { intervsi }\end{array}$ & $\begin{array}{c}\text { Bottom of } \\
\text { screened } \\
\text { interval }\end{array}$ \\
\hline & & & \multicolumn{4}{|c|}{ feet beiow isnd-surface } \\
\hline USGS-PZD & 361410115142601 & May 18 & 703 & 697 & 677 & 687 \\
\hline USGS-PZM & 361410115142602 & May 18 & 703 & 467 & 447 & 457 \\
\hline USGS-PZS & 361410115142603 & May 18 & 703 & 320 & 300 & 310 \\
\hline USGS-EXT1 & 361410115142604 & April 3 & 800 & 780 & -- & -- \\
\hline
\end{tabular}

postpones the onset of casing deformation and failure associated with aquifer-system compaction (Riley, 1986). The 6-in. extensometer casing at the Lorenzi site includes four $10-\mathrm{ft}$ long slip joints. The annular space around the conductor casing is cemented to a depth of $52 \mathrm{ft}$ below land surface. The annular space around the telescoping casing is filled with a heavy bentonite mud. A 2-in. diameter steel extensometer pipe is placed inside the telescoping casing. The extensometer pipe rests atop a cement plug at the bottom of the borehole at a depth of $780 \mathrm{ft}$ below land surface (fig. 4).

A steel extensometer table sits over the extensometer borehole. The table is supported by two steel table legs, which are encased in PVC and anchored $12 \mathrm{ft}$ below land surface. The anchored legs help isolate the table from shallow sediment deformation caused by changes in soil temperature or moisture content. Vertical deformation (compaction or expansion) of the aquifer system is measured by the movement of the table relative to the extensometer pipe. This movement is recorded with a linear potentiometer, an analog chart recorder, and a dial gage (fig. 5). The linear potentiometer is connected to the extensometer table and the top of the extensometer pipe. The analog chart recorder sits atop the extensometer table and is connected to the extensometer pipe by a counterweighted pulley system. The dial gage is attached to the extensometer table and a reference surface attached to the extensometer pipe.

The extensometer pipe is supported above ground by an asymmetric lever system counterbalanced with steel weights. The weight of the extensometer pipe is supported to minimize flexing of the pipe in the borehole. The lever arm is kept level to ensure that the extensometer pipe is aligned with the recording instruments and to further reduce flexing of the extensometer pipe. Riley (1986) indicates flexing of the pipe can result in frictional forces between the pipe and the steel casing, which can degrade the extensometer data. The asymmetric lever system provides a mechanical advantage of $8: 1$, which reduces the amount of the counterweight needed to support the extensometer pipe.

Riley (1986) describes the complex frictionalstress relations that may occur between an off-vertical casing and a slightly bent extensometer pipe. To quantify the frictional properties of an extensometer, characterize its overall performance, develop confidence in the reliability of its record, and refine the ideal amount of lever counterweight, a dead-band test is performed. The test consists of adding and removing lever counterweights to test the extensometer's ability to return the lever arm to the same position for equal amounts of weight. The dead band of an extensometer is the distance between starting and ending points for equal weights; each amount of weight may have its own dead band. The amount of weight with the smallest dead band is typically the ideal weight for the lever arm (D.L. Galloway, U.S. Geological Survey, oral commun., 2000). Dead-band tests for USGS-EXT1 indicate that $250 \mathrm{lbs}$ of counterweights provide the smallest dead band.

In spite of the above measures, completely eliminating downhole friction in an extensometer is practically impossible and many extensometers experience a degradation of data due to frictional stresses. Step-like shifts in the data are the most noticeable result of downhole friction. These shifts, or "stick-slips," are a result of the extensometer pipe instantaneously releasing frictional pressure that has accumulated over time (Riley, 1986). 


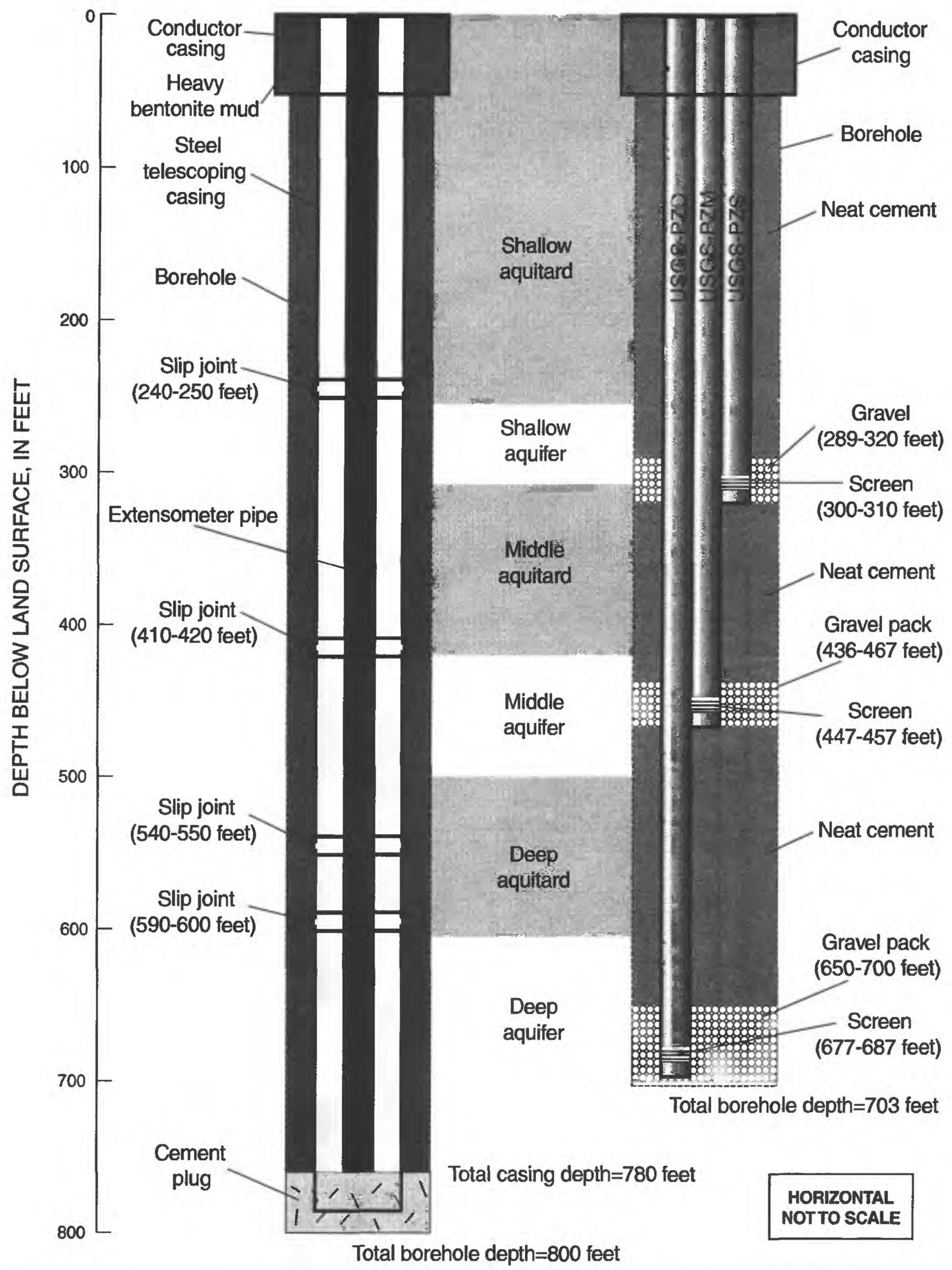

Figure 4. Below-ground construction of the extensometer and piezometers at the Lorenzi site, Las Vegas, Nevada. 


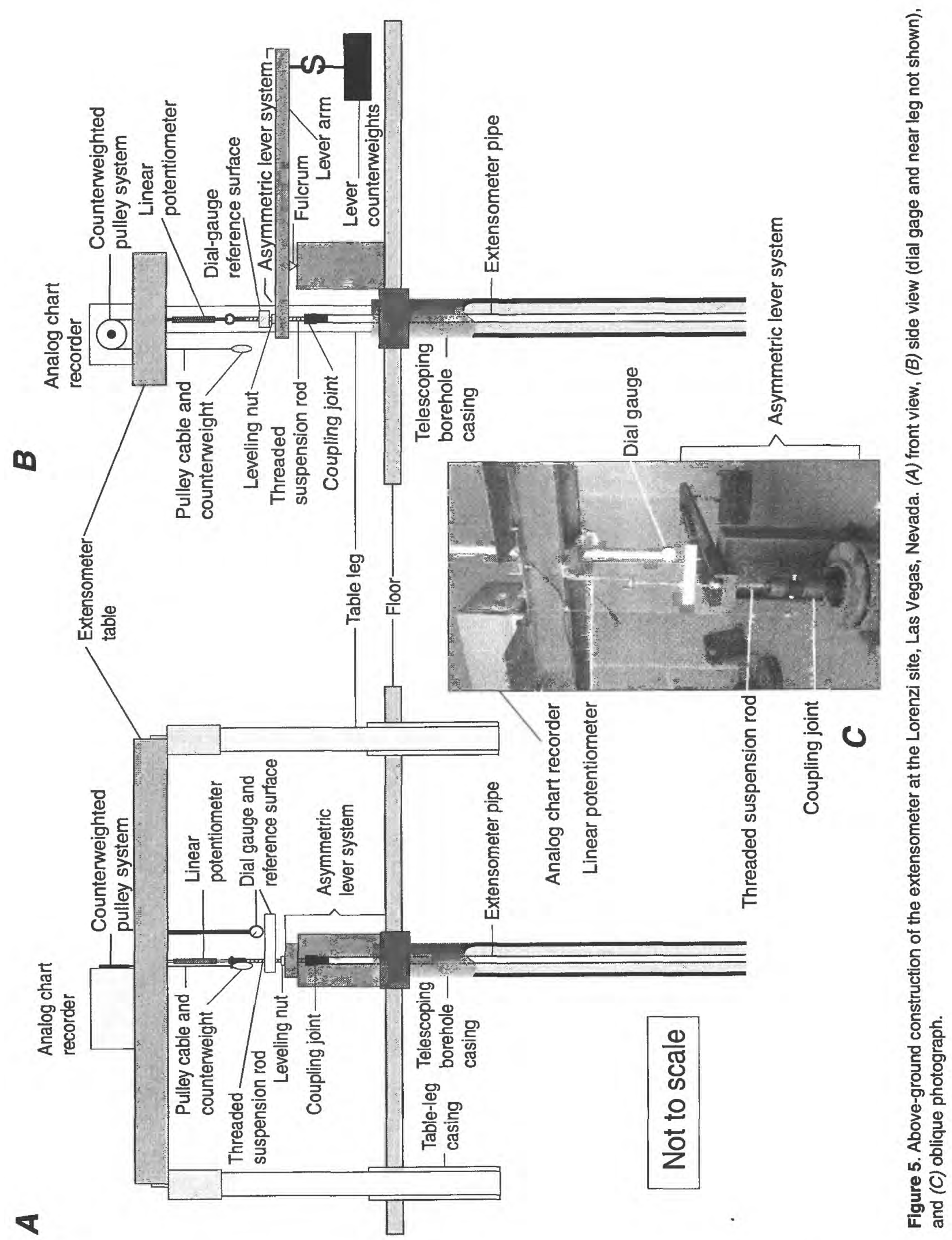




\section{GROUND-WATER LEVELS}

The depth to water in each piezometer at the Lorenzi site is measured periodically with a graduated steel tape or a calibrated electronic tape (table 2). The graduated steel tape is the preferred device to measure the depth to water because it typically is more accurate than the electronic tape, which is more susceptible to stretching. Steel tape measurements are reported to $0.01 \mathrm{ft}$ and electronic tape measurements are reported to $0.1 \mathrm{ft}$. The electronic tape is used mainly to measure depth to water when there is excessive condensation in the piezometer casing or when the depth to water is rapidly changing.

The depth to water in each piezometer also is continually monitored with submersible pressure transducers. The transducers in USGS-PZS and USGS-PZM have a pressure range of 0 to $30 \mathrm{lbs} / \mathrm{in}^{2}$ and the transducer in USGS-PZD has a pressure range of 0 to 50 $\mathrm{lbs} / \mathrm{in}^{2}$. Transducer pressure readings are converted to depth to water and reported to $0.01 \mathrm{ft}$, which is within the resolution of the transducers. The reported values are not intended to represent the absolute accuracy of the depth-to-water measurements because the transducer measurements are affected by the accuracy of the periodic steel-tape measurements, which are used to calibrate the transducers.

Each transducer is vented at land surface to minimize the potential effects of atmospheric barometricpressure changes on transducer measurements. Each transducer also measures ground-water temperature. Ground-water-temperature fluctuations can change water density and affect transducer measurements. Barometric pressure is measured at the site with a barometric-pressure sensor that has a range of 800 to 1,100 millibars. Barometric-pressure data are used to determine if barometric-pressure changes affect transducer measurements. Depth to water, water temperature, and barometric pressure are recorded every hour on an electronic data logger.

Continual depth-to-water data for each piezometer, from November 1994 through December 1999, are summarized in table 3 and shown in figure $6 A$. During the period of record, continual depth-to-water measurements ranged from 221.1 to $243.5 \mathrm{ft}$ below land surface in USGS-PZS; 251.9 to $311.5 \mathrm{ft}$ below land surface in USGS-PZM; and 251.5 to $328.8 \mathrm{ft}$ below land surface in USGS-PZD. The variance of depth to water in USGS-PZS (22.4 ft) is considerably less than in USGSPZM (59.6 ft) and USGS-PZD (77.3 ft). Although
USGS-PZS water-level fluctuations are smaller in magnitude, water levels in all three piezometers respond to system stresses in a similar manner (figs. $6 \mathrm{~A}$ and $7 B$ ).

During the period of record, LVVWD wells near the Lorenzi site generally were pumped during summer months (May through September) and (or) artificially recharged during the remainder of the year (Erin Cole, Las Vegas Valley Water District, written commun., 2000). Water levels in all three piezometers cyclically fluctuated in a manner consistent with the seasonal periods of pumping and artificial recharge. Water levels declined during periods of pumping and rose during periods of artificial recharge. From 1995 to 1997 , annual maximum water levels were relatively constant and annual minimum water levels declined in piezometers USGS-PZM and USGS-PZD. From 1997 to 1999 , annual maximum and minimum water levels rose in all three piezometers (fig. $6 \mathrm{~A}$ ). This general trend is consistent with increased amounts of artificial recharge that began during the winter of 1997-98 (Erin Cole, Las Vegas Valley Water District, written commun., 2000).

Production wells were diurnally pumped during pumping seasons from 1997 to 1999 ; wells were pumped during the night and the morning and turned off during the day. Prior to 1997, production wells were pumped more continuously during pumping seasons (Erin Cole, Las Vegas Valley Water District, written commun., 2000). Diurnal ground-water pumpage in 1999 and the responses of Lorenzi site ground-water levels are shown in figures 7 and 8 . Water levels declined during the pumping season, but fluctuated daily as production wells were cyclically pumped. During periods when daily ground-water pumpage was temporarily decreased, water levels in the piezometers temporarily rose (fig. 7). During seasons of diurnal pumping when pumps were turned off, water levels rose (fig. 8).

Ground-water levels for each piezometer for the period of record are shown in figure $6 \mathrm{~A}$. Ground-water levels during the 1995 season of near-continuous pumping are shown in figures $9 A$ and 10 . During seasons of near-continuous pumping, water levels generally decline linearly, except for periods when pumping is reduced. Ground-water levels during the 1999 season of diurnal pumping are shown in figures $7 B$ and $8 B$. During seasons of diurnal pumping, a trend of waterlevel decline is superposed by daily water-level fluctuations. Reductions in daily pumpage result in smaller daily fluctuations (fig. 7). Water levels rise during the 
Table 2. Periodic depth-to-water measurements in piezometers at the Lorenzi site, Las Vegas, Nevada, 1995-99

[Depth to water: referenced to land-surface; precision of depth to water indicates measurement accuracy; --, water level was not measured or measurement was rejected during data review.

Method: S, steel tape; T, electronic tape; NA, not applicable.

Site status: J, water level measured during artificial recharge of nearby production wells; $\mathrm{S}$, water level measured during pumping of nearby production wells; $T$, water level measured after pumping of nearby production wells; $U$, unknown; $Z$, other]

\begin{tabular}{|c|c|c|c|c|c|c|c|}
\hline \multicolumn{8}{|c|}{ Water-level measurement } \\
\hline \multirow[b]{2}{*}{ Date } & \multicolumn{2}{|c|}{ USGS-PZD } & \multicolumn{2}{|c|}{ USGS-PZM } & \multicolumn{2}{|c|}{ USGS-PZS } & \multirow[b]{2}{*}{ Site status } \\
\hline & $\begin{array}{l}\text { Depth to water } \\
\text { (feet) }\end{array}$ & Method & $\begin{array}{l}\text { Depth to water } \\
\text { (feet) }\end{array}$ & Method & $\begin{array}{l}\text { Depth to water } \\
\text { (feet) }\end{array}$ & Mathod & \\
\hline \multicolumn{8}{|c|}{1995} \\
\hline $04 / 14 / 95$ & 276 & $\mathbf{S}$ & 274 & $\mathbf{S}$ & 232 & $\mathrm{~S}$ & $\mathbf{Z}$ \\
\hline $05 / 09 / 95$ & 277 & $\mathrm{~S}$ & 275 & $\mathbf{S}$ & 232 & $\mathbf{S}$ & $\mathbf{T}$ \\
\hline $06 / 12 / 95$ & 283 & $\mathbf{S}$ & 275 & $\mathbf{S}$ & 232 & $\mathrm{~S}$ & $\mathbf{S}$ \\
\hline $07 / 28 / 95$ & 301 & $\mathrm{~S}$ & 286 & $\mathbf{S}$ & 238 & $\mathrm{~S}$ & $\mathbf{S}$ \\
\hline $08 / 29 / 95$ & 309 & $\mathbf{S}$ & - & NA & 240 & $\mathrm{~S}$ & $\mathrm{~S}$ \\
\hline $10 / 10 / 95$ & 306 & $\mathbf{S}$ & - & NA & 241 & $\mathbf{S}$ & $\mathbf{Z}$ \\
\hline $11 / 03 / 95$ & 299 & $\mathrm{~S}$ & - & NA & - & NA & $\mathbf{Z}$ \\
\hline \multicolumn{8}{|c|}{1996} \\
\hline 04/01/96 & 277 & $T$ & 274 & $\mathrm{~T}$ & 233 & $\mathrm{~T}$ & $\mathrm{Z}$ \\
\hline $04 / 30 / 96$ & 276 & $T$ & 273 & $\mathrm{~T}$ & -- & NA & $\mathbf{Z}$ \\
\hline $07 / 02 / 96$ & 298 & $T$ & 285 & $T$ & 238 & $T$ & $\mathbf{S}$ \\
\hline $07 / 31 / 96$ & 306 & $\mathbf{S}$ & 291 & $\mathbf{S}$ & 239 & $\mathrm{~S}$ & $T$ \\
\hline 09/16/96 & 311 & $\mathrm{~T}$ & 301 & $\mathbf{T}$ & 243 & $\mathrm{~T}$ & $\mathbf{Z}$ \\
\hline $10 / 09 / 96$ & 311 & $T$ & 300 & $T$ & - & NA & $\mathrm{S}$ \\
\hline $10 / 22 / 96$ & 310 & $T$ & 300 & $T$ & 243 & $\mathbf{S}$ & $\mathbf{Z}$ \\
\hline $11 / 05 / 96$ & 301.90 & S & 295.77 & $\mathrm{~S}$ & 241.50 & $\mathrm{~S}$ & $\mathrm{U}$ \\
\hline $11 / 05 / 96$ & -- & NA & 295.66 & $\mathbf{S}$ & -- & NA & $\mathrm{U}$ \\
\hline $11 / 06 / 96$ & -- & NA & 295.87 & $\mathbf{S}$ & -- & NA & $\mathrm{U}$ \\
\hline $11 / 07 / 96$ & 301.97 & $\mathrm{~S}$ & 295.98 & $\mathrm{~S}$ & 241.86 & $\mathrm{~S}$ & $\mathrm{U}$ \\
\hline $11 / 08 / 96$ & 301.63 & $\mathrm{~S}$ & 295.71 & $\mathrm{~S}$ & 241.74 & $\mathrm{~S}$ & $\mathbf{U}$ \\
\hline $11 / 13 / 96$ & 301.63 & $\mathbf{S}$ & 295.20 & $\mathbf{S}$ & 241.22 & $\mathrm{~S}$ & $\mathbf{J}$ \\
\hline $11 / 25 / 96$ & 297.3 & $\mathrm{~T}$ & 292.89 & $\mathbf{S}$ & 240.38 & $\mathbf{S}$ & $\mathbf{J}$ \\
\hline $12 / 18 / 96$ & 292.0 & $\mathbf{T}$ & 289.3 & $T$ & 238.9 & $\mathbf{T}$ & $\mathbf{J}$ \\
\hline $12 / 19 / 96$ & 291.3 & $\mathrm{~T}$ & 288.9 & $T$ & 238.6 & $T$ & $\mathbf{J}$ \\
\hline $12 / 19 / 96$ & 291.0 & $\mathrm{~T}$ & 288.8 & $T$ & 238.4 & $T$ & $\mathbf{J}$ \\
\hline \multicolumn{8}{|c|}{1997} \\
\hline $01 / 14 / 97$ & 284.9 & $\mathrm{~T}$ & 283.86 & $\mathrm{~S}$ & 236.26 & $\mathrm{~S}$ & J \\
\hline $02 / 12 / 97$ & 283.1 & $\mathrm{~T}$ & 280.22 & $\mathbf{S}$ & 234.10 & $\mathrm{~S}$ & $\mathrm{U}$ \\
\hline $02 / 12 / 97$ & 282.5 & $T$ & - & NA & - & NA & $\mathrm{U}$ \\
\hline $03 / 12 / 97$ & 278.6 & $T$ & 276.69 & $\mathrm{~S}$ & 232.97 & $\mathrm{~S}$ & $\mathbf{U}$ \\
\hline $03 / 15 / 97$ & 278.1 & $\mathrm{~T}$ & - & NA & - & NA & $\mathrm{U}$ \\
\hline $03 / 19 / 97$ & 278.9 & $\mathrm{~T}$ & 276.55 & $\mathbf{S}$ & 233.27 & S & $\mathbf{J}$ \\
\hline $04 / 03 / 97$ & 277.3 & $\mathrm{~T}$ & 274.87 & $\mathbf{S}$ & 232.47 & $\mathrm{~S}$ & $\mathbf{J}$ \\
\hline $05 / 06 / 97$ & 279.53 & $\mathrm{~T}$ & 275.84 & $\mathrm{~S}$ & 233.28 & $\mathrm{~S}$ & $\mathbf{J}$ \\
\hline $05 / 07 / 97$ & - & NA & 275.9 & $T$ & - & NA & $\mathrm{U}$ \\
\hline $05 / 08 / 97$ & 280.3 & $\mathbf{T}$ & 275.98 & $\mathrm{~S}$ & 233.22 & $\mathbf{S}$ & $\mathrm{U}$ \\
\hline
\end{tabular}


Table 2. Periodic depth-to-water measurements in piezometers at the Lorenzi site, Las Vegas, Nevada, 1995-99-Continued

\begin{tabular}{|c|c|c|c|c|c|c|c|}
\hline \multicolumn{8}{|c|}{ Water-level measurement } \\
\hline \multirow[b]{2}{*}{ Date } & \multicolumn{2}{|c|}{ USGS-PZD } & \multicolumn{2}{|c|}{ USGS-PZM } & \multicolumn{2}{|c|}{ USGS-PZS } & \multirow[b]{2}{*}{ Site statue } \\
\hline & $\begin{array}{l}\text { Depth to water } \\
\text { (feet) }\end{array}$ & Method & $\begin{array}{c}\text { Depth to water } \\
\text { (feet) }\end{array}$ & Method & $\begin{array}{c}\text { Depth to water } \\
\text { (feet) }\end{array}$ & Method & \\
\hline \multicolumn{8}{|c|}{ 1997-Continued } \\
\hline 05/09/97 & -- & NA & 275.6 & $\mathrm{~T}$ & - & NA & $\mathbf{U}$ \\
\hline $05 / 13 / 97$ & 280.8 & $\mathrm{~T}$ & 276.13 & $\mathbf{S}$ & 233.37 & $\mathrm{~S}$ & $\mathbf{J}$ \\
\hline 05/19/97 & 285.9 & $\mathrm{~T}$ & 278.7 & $\mathrm{~T}$ & 233.9 & $\mathrm{~T}$ & $\mathrm{~T}$ \\
\hline 06/06/97 & 301.4 & $\mathrm{~T}$ & 286.2 & $\mathrm{~T}$ & 235.22 & $\mathbf{S}$ & $\mathbf{S}$ \\
\hline 07/08/97 & 312.3 & $\mathrm{~T}$ & 294.92 & $\mathbf{S}$ & 238.38 & $\mathbf{S}$ & $\mathbf{S}$ \\
\hline 08/07/97 & 317.7 & $\mathbf{T}$ & 301.34 & $\mathbf{S}$ & 240.35 & $\mathbf{S}$ & $\mathbf{S}$ \\
\hline 09/03/97 & 312.2 & $\mathbf{T}$ & 306.0 & $\mathrm{~T}$ & 241.69 & $\mathbf{S}$ & $\mathrm{T}$ \\
\hline 09/03/97 & - & NA & 303.6 & $\mathrm{~T}$ & - & NA & $\mathrm{T}$ \\
\hline $09 / 23 / 97$ & 318.8 & $\mathrm{~T}$ & 308.54 & $\mathbf{S}$ & 241.71 & $\mathrm{~S}$ & $\mathrm{~T}$ \\
\hline $09 / 24 / 97$ & 319.9 & $\mathrm{~T}$ & - & NA & - & NA & $\mathrm{T}$ \\
\hline $09 / 24 / 97$ & 318.8 & $\mathrm{~T}$ & - & NA & -- & NA & $\mathrm{T}$ \\
\hline $09 / 25 / 97$ & 320.6 & $\mathrm{~T}$ & 309.4 & $\mathrm{~T}$ & 241.7 & $\mathrm{~T}$ & $T$ \\
\hline $10 / 03 / 97$ & 314.3 & $\mathrm{~T}$ & 307.4 & $T$ & 241.5 & $\mathrm{~T}$ & $\mathbf{S}$ \\
\hline $10 / 30 / 97$ & 305.8 & $\mathrm{~T}$ & 302.4 & $\mathrm{~T}$ & 241.7 & $\mathrm{~T}$ & $\mathbf{J}$ \\
\hline $12 / 01 / 97$ & 294.0 & $\mathrm{~T}$ & 293.0 & $\mathrm{~T}$ & 239.2 & $\mathrm{~T}$ & $\mathbf{J}$ \\
\hline $12 / 12 / 97$ & 291.5 & $\mathrm{~T}$ & 290.8 & $\mathrm{~T}$ & 238.9 & $\mathrm{~T}$ & $\mathbf{J}$ \\
\hline $12 / 22 / 97$ & 288.0 & $\mathrm{~T}$ & -- & NA & -- & NA & $\mathbf{J}$ \\
\hline \multicolumn{8}{|c|}{1998} \\
\hline $01 / 08 / 98$ & 282.8 & $\mathrm{~T}$ & 283.0 & $\mathrm{~T}$ & 235.9 & $\mathrm{~T}$ & $\mathbf{J}$ \\
\hline $02 / 13 / 98$ & 278.5 & $\mathrm{~T}$ & 276.34 & $\mathrm{~S}$ & 231.94 & $\mathrm{~S}$ & $\mathbf{J}$ \\
\hline $02 / 26 / 98$ & 273.8 & $\mathrm{~T}$ & 272.48 & $\mathbf{S}$ & 230.33 & $\mathbf{S}$ & $\mathbf{J}$ \\
\hline $03 / 24 / 98$ & 271.7 & $T$ & 269.1 & $\mathrm{~T}$ & 228.2 & $\mathrm{~T}$ & $\mathrm{~J}$ \\
\hline $03 / 27 / 98$ & 272.2 & $\mathrm{~T}$ & 269.6 & $\mathrm{~T}$ & 227.9 & $\mathrm{~T}$ & $\mathbf{J}$ \\
\hline $04 / 23 / 98$ & 268.6 & $\mathrm{~T}$ & 266.6 & $\mathrm{~T}$ & 227.0 & $\mathrm{~T}$ & $\mathbf{J}$ \\
\hline $05 / 12 / 98$ & 270.9 & $\mathrm{~T}$ & 267.8 & $\mathrm{~T}$ & 227.4 & $\mathrm{~T}$ & $\mathbf{J}$ \\
\hline $06 / 11 / 98$ & 286.7 & $\mathrm{~T}$ & 277.4 & $T$ & 229.8 & $\mathbf{T}$ & $\mathrm{T}$ \\
\hline $06 / 25 / 98$ & 296.7 & $\mathrm{~T}$ & 282.3 & $\mathrm{~T}$ & 231.3 & $\mathrm{~T}$ & $\mathrm{~T}$ \\
\hline $06 / 25 / 98^{\circ}$ & 291.4 & $\mathrm{~T}$ & - & NA & - & NA & $T$ \\
\hline $07 / 13 / 98$ & 302.1 & $\mathrm{~T}$ & 287.1 & $\mathrm{~T}$ & 233.8 & $\mathrm{~T}$ & $\mathrm{~T}$ \\
\hline $08 / 05 / 98$ & 300.9 & $\mathrm{~T}$ & 290.1 & $\mathbf{T}$ & 236.1 & $\mathrm{~T}$ & $\mathrm{~T}$ \\
\hline 08/06/98 & - & NA & -- & NA & 236.2 & $\mathrm{~T}$ & $\mathrm{~T}$ \\
\hline $08 / 20 / 98$ & 312.8 & $\mathrm{~T}$ & 296.3 & $\mathrm{~T}$ & 237.2 & $T$ & $\mathbf{S}$ \\
\hline $08 / 21 / 98$ & 313.6 & $\mathrm{~T}$ & -- & NA & - & NA & $\mathbf{S}$ \\
\hline $09 / 14 / 98$ & 308.4 & $\mathrm{~T}$ & 299.0 & $\mathrm{~T}$ & 237.5 & $\mathbf{T}$ & $\mathrm{T}$ \\
\hline $09 / 28 / 98$ & 319.3 & $\mathrm{~T}$ & 304.3 & $\mathrm{~T}$ & 238.5 & $\mathrm{~T}$ & $\mathbf{S}$ \\
\hline $09 / 28 / 98$ & 316.0 & $\mathrm{~T}$ & -- & NA & - & NA & $\mathrm{T}$ \\
\hline $10 / 29 / 98$ & 293.34 & $\mathbf{S}$ & 291.43 & $\mathbf{S}$ & 238.40 & $\mathbf{S}$ & $\mathbf{J}$ \\
\hline $11 / 25 / 98$ & 283.59 & $\mathbf{S}$ & 283.56 & $\mathbf{S}$ & 236.20 & $\mathrm{~S}$ & $\mathbf{J}$ \\
\hline $12 / 22 / 98$ & 276.01 & $\mathrm{~S}$ & 276.86 & $\mathbf{S}$ & 233.13 & $\mathbf{S}$ & $\mathbf{J}$ \\
\hline
\end{tabular}


Table 2. Periodic depth-to-water measurements in piezometers at the Lorenzi site, Las Vegas, Nevada, 1995-99-Continued

\begin{tabular}{|c|c|c|c|c|c|c|c|}
\hline \multicolumn{8}{|c|}{ Water-level measurement } \\
\hline \multirow[b]{2}{*}{ Date } & \multicolumn{2}{|c|}{ USGS-PZD } & \multicolumn{2}{|c|}{ USGS-PZM } & \multicolumn{2}{|c|}{ USGS-PZS } & \multirow[b]{2}{*}{ Site statua } \\
\hline & $\begin{array}{c}\text { Depth to water } \\
\text { (feet) }\end{array}$ & Method & $\begin{array}{l}\text { Depth to water } \\
\text { (feet) }\end{array}$ & Method & $\begin{array}{l}\text { Depth to water } \\
\text { (feet) }\end{array}$ & Method & \\
\hline \multicolumn{8}{|c|}{1999} \\
\hline $01 / 21 / 99$ & 268.04 & $\mathrm{~S}$ & 269.44 & $\mathbf{S}$ & 229.73 & $\mathrm{~S}$ & J \\
\hline 02/01/99 & 265.6 & $\mathbf{T}$ & - & NA & - & NA & $\mathbf{J}$ \\
\hline $02 / 08 / 99$ & 263.65 & $\mathbf{S}$ & 265.28 & $\mathbf{S}$ & 227.40 & $\mathrm{~S}$ & $\mathbf{J}$ \\
\hline $02 / 10 / 99$ & 263.3 & $\mathrm{~T}$ & 265.0 & $\mathrm{~T}$ & 227.3 & $\mathrm{~T}$ & $\mathbf{J}$ \\
\hline $02 / 10 / 99$ & 263.4 & $\mathrm{~T}$ & 265.0 & $\mathrm{~T}$ & 227.3 & $\mathrm{~T}$ & $\mathbf{J}$ \\
\hline $02 / 22 / 99$ & 260.74 & $\mathbf{S}$ & 262.47 & $\mathbf{S}$ & 226.30 & $\mathbf{S}$ & $\mathbf{J}$ \\
\hline $02 / 28 / 99$ & 259.79 & $\mathrm{~S}$ & 261.32 & $\mathbf{S}$ & 225.73 & $\mathrm{~S}$ & J \\
\hline $03 / 18 / 99$ & 257.53 & $\mathrm{~S}$ & 258.38 & $\mathrm{~S}$ & 224.37 & $\mathrm{~S}$ & $\mathbf{J}$ \\
\hline 03/29/99 & 258.67 & $\mathrm{~S}$ & 258.04 & $\mathrm{~S}$ & 223.86 & $\mathrm{~S}$ & J \\
\hline $04 / 11 / 99$ & 256.79 & $S$ & 256.22 & $\mathrm{~S}$ & 223.08 & $\mathrm{~S}$ & $J$ \\
\hline $04 / 28 / 99$ & 252.73 & $\mathbf{S}$ & 252.99 & $\mathrm{~S}$ & 222.06 & $\mathrm{~S}$ & $\mathbf{J}$ \\
\hline $05 / 05 / 99$ & 252.19 & $\mathrm{~S}$ & 252.30 & $\mathbf{S}$ & 221.70 & $\mathbf{S}$ & $\mathbf{J}$ \\
\hline $05 / 28 / 99$ & 256.69 & $\mathrm{~S}$ & 252.49 & $\mathrm{~S}$ & 221.53 & $\mathrm{~S}$ & $\mathbf{J}$ \\
\hline $06 / 24 / 99$ & 279.81 & $\mathrm{~S}$ & 265.42 & $\mathrm{~S}$ & 224.26 & $\mathbf{S}$ & $\mathbf{S}$ \\
\hline $07 / 13 / 99$ & 281.9 & $\mathrm{~T}$ & 270.6 & $\mathrm{~T}$ & 226.73 & $\mathrm{~S}$ & $\mathrm{~T}$ \\
\hline $08 / 10 / 99$ & 294.43 & $\mathrm{~S}$ & 279.17 & $\mathrm{~S}$ & 230.55 & $\mathrm{~S}$ & $\mathrm{~T}$ \\
\hline $09 / 27 / 99$ & 309.86 & $\mathrm{~S}$ & 292.82 & $\mathrm{~S}$ & 234.86 & $\mathbf{S}$ & $\mathbf{T}$ \\
\hline $10 / 18 / 99$ & 285.27 & $\mathrm{~S}$ & 282.38 & $\mathbf{S}$ & 235.65 & $\mathbf{S}$ & $\mathbf{J}$ \\
\hline $11 / 17 / 99$ & 272.18 & $S$ & 272.10 & $\mathrm{~S}$ & 232.65 & $\mathrm{~S}$ & $\mathbf{J}$ \\
\hline $12 / 15 / 99$ & 266.49 & $\mathrm{~S}$ & 266.14 & $\mathrm{~S}$ & 229.10 & $\mathrm{~S}$ & $\mathbf{J}$ \\
\hline
\end{tabular}


Table 3. Summary of continual depth-to-water measurements in piezometers at the Lorenzi site, Las Vegas, Nevada, 1994-99

[Depth-to-water measurements are referenced to land surface. Depth-to-water statistics are rounded from the recorded values to the nearest $0.1 \mathrm{ft}$. Min., minimum hourly value; Mean, average of hourly values; Max., maximum hourly value; value in parentheses is the number of missing hours for indicated period; *, November 1994 consists of only 14 days and 10 hours of measurements; **, 1994 annual values are derived from less than two months of measurements; --, no data]

\begin{tabular}{|c|c|c|c|c|c|c|c|c|c|c|c|c|}
\hline \multirow{3}{*}{ Month } & \multicolumn{4}{|c|}{ USGS-PZD } & \multicolumn{4}{|c|}{ USGS-PZM } & \multicolumn{4}{|c|}{ USGS-PZS } \\
\hline & & \multicolumn{3}{|c|}{ Depth to water } & & \multicolumn{3}{|c|}{ Depth to water } & & \multicolumn{3}{|c|}{ Depth to water } \\
\hline & & Min. & Mean & Mex. & & Min. & Meen & Max. & & MIn. & Mean & Max. \\
\hline \multicolumn{13}{|c|}{1994} \\
\hline November * & & 295.7 & 297.1 & 298.4 & & 292.4 & 293.4 & 294.2 & & 240.1 & 240.7 & 241.3 \\
\hline December & (2) & 290.0 & 293.0 & 296.0 & & 288.2 & 290.3 & 292.3 & & 237.8 & 239.1 & 240.3 \\
\hline Annual ** & & 290.0 & 295.0 & 298.4 & & 288.2 & 291.8 & 294.2 & & 237.8 & 239.9 & 241.3 \\
\hline \multicolumn{13}{|c|}{1995} \\
\hline January & & 284.0 & 286.8 & 290.1 & & 283.3 & 285.6 & 288.2 & & 235.1 & 236.4 & 238.0 \\
\hline February & & 280.0 & 281.9 & 284.1 & & 279.3 & 281.2 & 283.3 & & 233.8 & 234.4 & 235.2 \\
\hline March & (28) & 276.2 & 278.0 & 280.0 & & 275.5 & 277.4 & 279.3 & & 232.3 & 233.1 & 233.8 \\
\hline April & & 274.8 & 275.9 & 278.5 & & 273.2 & 274.2 & 275.5 & & 231.5 & 231.9 & 232.4 \\
\hline May & & 277.5 & 280.4 & 284.2 & & 274.0 & 275.6 & 277.4 & & 231.6 & 232.2 & 232.8 \\
\hline June & (95) & 281.4 & 284.6 & 291.0 & (95) & 275.4 & 276.8 & 279.2 & (95) & 232.5 & 233.8 & 235.1 \\
\hline July & & 290.2 & 297.0 & 301.9 & & 279.3 & 283.5 & 287.1 & & 235.0 & 236.5 & 238.1 \\
\hline August & & 301.7 & 305.4 & 309.7 & & 287.1 & 290.4 & 293.6 & & 237.9 & 239.0 & 239.8 \\
\hline September & (25) & 308.7 & 309.7 & 312.0 & & 293.6 & 295.7 & 297.9 & & 239.8 & 240.4 & 241.0 \\
\hline October & & 299.1 & 304.0 & 309.0 & & 292.6 & 295.1 & 297.0 & & 240.2 & 240.6 & 241.0 \\
\hline November & & 292.5 & 296.4 & 299.2 & & 288.7 & 291.0 & 292.8 & & 238.4 & 239.5 & 240.4 \\
\hline December & (49) & 285.8 & 289.2 & 292.5 & (18) & 283.5 & 286.2 & 288.7 & (33) & 236.1 & 237.5 & 238.4 \\
\hline Annual & (197) & 274.8 & 290.8 & 312.0 & (113) & 273.2 & 284.4 & 297.9 & (128) & 231.5 & 236.3 & 241.0 \\
\hline \multicolumn{13}{|c|}{1996} \\
\hline January & & 282.2 & 284.4 & 285.9 & & 280.3 & 281.6 & 283.7 & & 234.2 & 235.3 & 236.4 \\
\hline February & & 281.0 & 283.5 & 285.3 & & 278.0 & 279.3 & 280.5 & & 233.4 & 234.0 & 234.6 \\
\hline March & (21) & 277.3 & 278.5 & 281.1 & & 274.6 & 276.0 & 278.1 & & 232.3 & 233.0 & 233.8 \\
\hline April & & 276.0 & 276.9 & 279.4 & & 272.8 & 273.7 & 274.8 & & 232.5 & 232.8 & 233.3 \\
\hline May & & 277.0 & 280.6 & 285.5 & & 273.1 & 275.2 & 276.6 & & 232.7 & 233.5 & 234.2 \\
\hline June & & 283.3 & 291.3 & 296.3 & (191) & 276.3 & 279.8 & 283.8 & & 234.2 & 235.7 & 237.2 \\
\hline July & & 295.4 & 301.7 & 306.1 & & 283.4 & 287.8 & 291.3 & & 236.3 & 238.2 & 239.5 \\
\hline August & & 306.2 & 313.4 & 321.3 & & 291.3 & 297.3 & 302.8 & & 239.2 & 240.5 & 241.8 \\
\hline September & (5) & 306.9 & 313.2 & 322.8 & & 299.5 & 302.1 & 305.1 & & 241.5 & 242.4 & 243.3 \\
\hline October & (228) & 305.0 & 308.2 & 314.3 & (228) & 298.1 & 299.7 & 301.4 & (228) & 242.6 & 243.0 & 243.5 \\
\hline November & (179) & 296.1 & 299.0 & 302.5 & (179) & 291.6 & 293.8 & 295.8 & (179) & 239.4 & 240.6 & 241.9 \\
\hline December & (9) & 287.7 & 292.7 & 299.5 & (3) & 286.2 & 289.4 & 292.4 & (3) & 237.3 & 238.6 & 239.8 \\
\hline Annual & (442) & 276.0 & 293.6 & 322.8 & $(601)$ & 272.8 & 286.3 & 305.1 & $(410)$ & 232.3 & 237.3 & 243.5 \\
\hline \multicolumn{13}{|c|}{1997} \\
\hline January & (238) & 282.0 & 285.1 & 287.7 & & 280.8 & 283.6 & 286.2 & & 235.0 & 236.1 & 237.4 \\
\hline February & (449) & 280.8 & 282.1 & 283.4 & & 277.9 & 279.6 & 283.3 & & 232.9 & 234.2 & 235.0 \\
\hline March & (348) & 277.6 & 278.3 & 279.2 & (129) & 275.8 & 276.9 & 278.7 & (2) & 232.8 & 233.2 & 233.7 \\
\hline April & & 276.4 & 278.7 & 282.2 & (720) & -- & -. & -- & & 232.3 & 232.8 & 233.3 \\
\hline May & (167) & 279.3 & 286.9 & 297.6 & (210) & 275.3 & 279.5 & 284.6 & (75) & 232.9 & 233.8 & 234.9 \\
\hline
\end{tabular}

14 Ground-Water and Aquifer-System-Compaction Data From the Lorenzi Site, Les Vegas, Nevade, 1994-99 
Table 3. Summary of continual depth-to-water measurements in piezometers at the Lorenzi site, Las Vegas, Nevada, 1994-99Continued

\begin{tabular}{|c|c|c|c|c|c|c|c|c|c|c|c|c|}
\hline \multirow{3}{*}{ Month } & \multicolumn{4}{|c|}{ USGS-PZD } & \multicolumn{4}{|c|}{ USGS-PZM } & \multicolumn{4}{|c|}{ USGS-PZS } \\
\hline & & \multicolumn{3}{|c|}{ Depth to water } & & \multicolumn{3}{|c|}{ Depth to water } & & \multicolumn{3}{|c|}{ Depth to water } \\
\hline & & Min. & Mean & Max. & & Min. & Mean & Max. & & Min. & Mean & Max. \\
\hline \multicolumn{13}{|c|}{ 1997-Continued } \\
\hline June & & 288.1 & 299.7 & 308.2 & & 281.4 & 287.6 & 292.5 & & 234.8 & 236.1 & 237.6 \\
\hline July & (1) & 297.6 & 309.8 & 318.0 & (1) & 289.7 & 295.8 & 300.5 & (1) & 237.4 & 239.0 & 240.1 \\
\hline August & & 306.2 & 314.0 & 323.0 & & 297.6 & 301.1 & 305.9 & & 239.9 & 240.8 & 241.8 \\
\hline September & (12) & 310.0 & 320.2 & 328.7 & & 302.5 & 307.2 & 311.2 & $(665)$ & 241.7 & 241.8 & 242.0 \\
\hline October & & 305.3 & 311.5 & 328.8 & & 301.9 & 305.6 & 311.5 & (63) & 241.2 & 241.8 & 242.3 \\
\hline November & & 294.2 & 299.2 & 305.3 & & 293.2 & 297.3 & 302.0 & & 239.2 & 240.6 & 241.8 \\
\hline December & (6) & 285.5 & 290.1 & 294.8 & & 285.1 & 289.4 & 293.2 & & 236.6 & 238.1 & 239.6 \\
\hline Annual & $(1,221)$ & 276.4 & 296.3 & 328.8 & $(1,060)$ & 275.3 & 291.2 & 311.5 & $(806)$ & 232.3 & 237.4 & 242.3 \\
\hline \multicolumn{13}{|c|}{1998} \\
\hline January & & 276.7 & 280.4 & 285.5 & & 276.6 & 280.6 & 285.1 & & 233.4 & 235.0 & 236.6 \\
\hline February & & 273.4 & 276.0 & 279.0 & & 272.2 & 274.8 & 276.6 & & 230.2 & 231.7 & 233.4 \\
\hline March & (6) & 269.3 & 271.4 & 273.4 & & 268.1 & 269.9 & 272.1 & & 227.4 & 228.8 & 230.3 \\
\hline April & & 267.2 & 269.2 & 271.8 & & 266.4 & 267.3 & 269.2 & (1) & 226.7 & 227.1 & 227.6 \\
\hline May & & 270.2 & 274.6 & 284.0 & & 267.2 & 269.8 & 274.6 & & 227.0 & 227.8 & 229.1 \\
\hline June & (5) & 277.8 & 289.1 & 299.2 & & 271.9 & 278.5 & 284.2 & $(5)$ & 229.0 & 230.3 & 232.3 \\
\hline July & & 289.1 & 298.3 & 306.6 & & 281.7 & 286.7 & 290.8 & (224) & 232.2 & 233.5 & 234.8 \\
\hline August & (1) & 296.6 & 307.4 & 317.3 & & 288.4 & 294.1 & 300.1 & (132) & 236.0 & 237.1 & 238.3 \\
\hline September & (3) & 303.5 & 311.5 & 320.0 & & 297.1 & 300.5 & 304.7 & & 237.4 & 238.0 & 238.7 \\
\hline October & & 292.7 & 298.9 & 319.4 & & 290.9 & 295.5 & 304.6 & & 238.1 & 238.7 & 239.2 \\
\hline November & & 281.8 & 286.3 & 292.7 & & 282.0 & 286.0 & 290.9 & & 235.4 & 236.8 & 238.1 \\
\hline December & (1) & 272.9 & 277.8 & 283.3 & (1) & 274.1 & 278.3 & 282.1 & & 231.5 & 233.8 & 235.5 \\
\hline Annual & (16) & 267.2 & 286.7 & 320.0 & (1) & 266.4 & 281.8 & 304.7 & $(362)$ & 226.7 & 233.2 & 239.2 \\
\hline \multicolumn{13}{|c|}{1999} \\
\hline January & & 265.4 & 269.5 & 274.9 & & 267.0 & 270.8 & 274.3 & & 228.4 & 230.3 & 231.8 \\
\hline February & (2) & 259.5 & 262.4 & 265.6 & & 261.1 & 264.0 & 267.2 & & 225.6 & 226.9 & 228.7 \\
\hline March & & 256.6 & 259.1 & 261.6 & & 257.4 & 259.3 & 261.2 & (1) & 223.4 & 224.4 & 225.5 \\
\hline April & & 252.5 & 256.2 & 258.0 & & 252.9 & 255.7 & 257.5 & (1) & 222.1 & 223.0 & 223.4 \\
\hline May & & 251.5 & 254.0 & 256.9 & & 251.9 & 252.5 & 253.3 & & 221.1 & 221.6 & 222.1 \\
\hline June & & 256.7 & 272.0 & 284.2 & & 252.3 & 260.8 & 268.1 & & 221.5 & 222.9 & 225.5 \\
\hline July & (1) & 275.6 & 283.8 & 291.8 & (1) & 266.2 & 271.2 & 276.2 & (1) & 225.4 & 227.3 & 229.4 \\
\hline August & & 282.9 & 293.3 & 303.0 & & 274.3 & 279.8 & 285.9 & & 229.3 & 231.1 & 232.6 \\
\hline September & & 294.5 & 303.2 & 310.7 & & 284.1 & 289.0 & 293.7 & & 232.5 & 234.0 & 235.4 \\
\hline October & & 278.2 & 285.8 & 296.9 & & 277.2 & 282.8 & 289.6 & & 234.8 & 235.4 & 236.0 \\
\hline November & & 268.5 & 273.5 & 278.2 & & 268.7 & 273.0 & 277.2 & & 230.9 & 233.1 & 234.8 \\
\hline December & & 262.1 & 265.8 & 269.2 & & 262.4 & 265.6 & 268.7 & & 226.4 & 228.9 & 230.9 \\
\hline Annual & (3) & 251.5 & 273.2 & 310.7 & (1) & 251.9 & 268.7 & 293.7 & (3) & 221.1 & 228.2 & 236.0 \\
\hline $\begin{array}{l}\text { Period of } \\
\text { record }\end{array}$ & $(1,881)$ & 251.5 & 288.6 & 328.8 & $(1,776)$ & 251.9 & 283.0 & 311.5 & $(1,709)$ & 221.1 & 234.8 & 243.5 \\
\hline
\end{tabular}



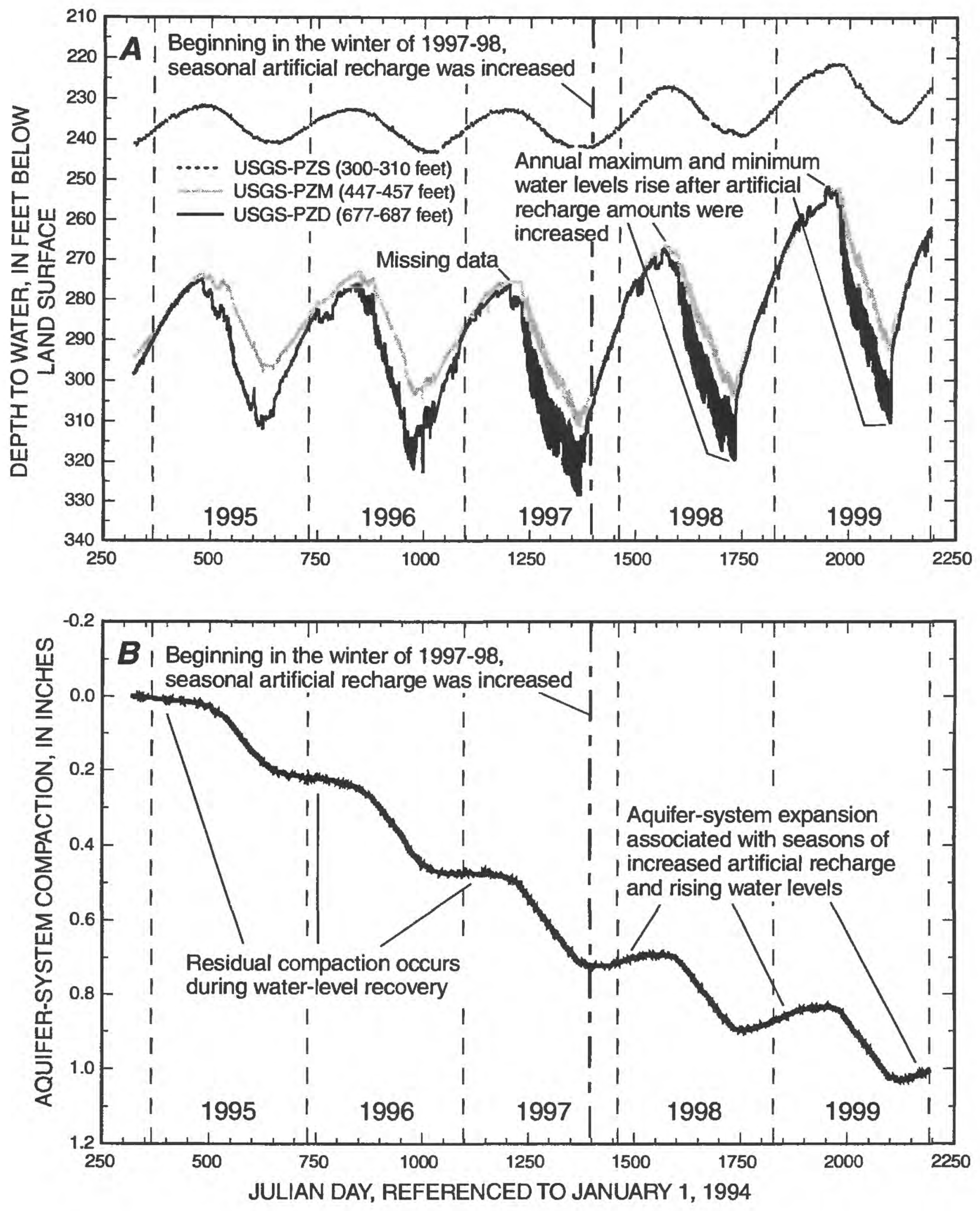

Figure 6. (A) Ground-water levels in piezometers USGS-PZS, -PZM, and -PZD and (B) aquifer-system compaction in extensometer USGS-EXT1, at the Lorenzi site, Las Vegas, Nevada, November 16, 1994December 31, 1999. 

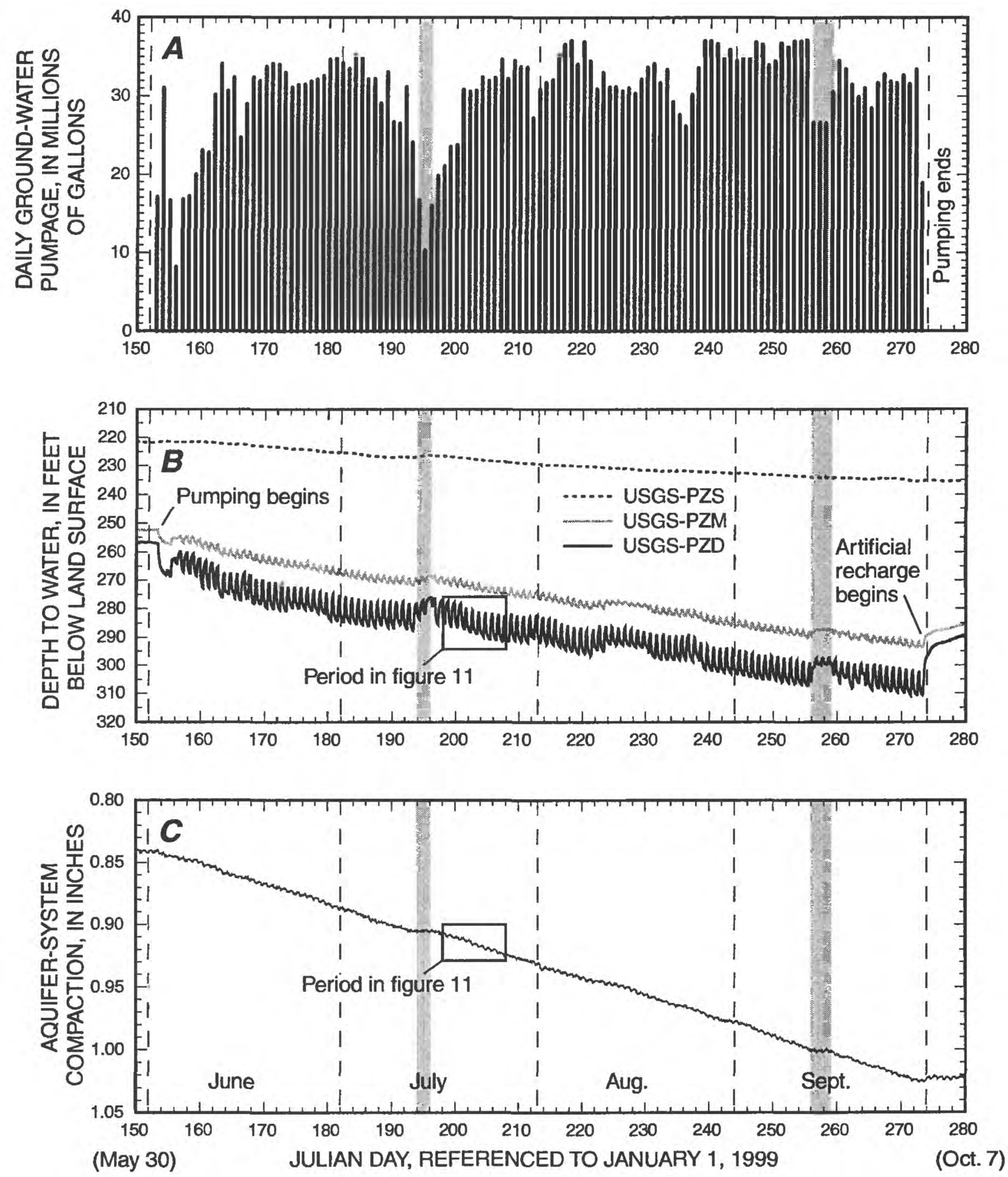

Figure 7. (A) Daily ground-water pumpage from production wells near the Lorenzi site, $(B)$ ground-water levels in piezometers USGS-PZS, -PZM, and -PZD, and (C) aquifer-system compaction in extensometer USGS-EXT1, during a season of diurnal pumping, at the Lorenzi site, Las Vegas, Nevada, May 30-October 7, 1999. [Groundwater pumpage in (A) is from LVVWD wells $28,29,33,69,72,88,92,94,101,103,116,117$. Shaded areas are periods when daily water levels remain high during periods of reduced ground-water pumpage.] 

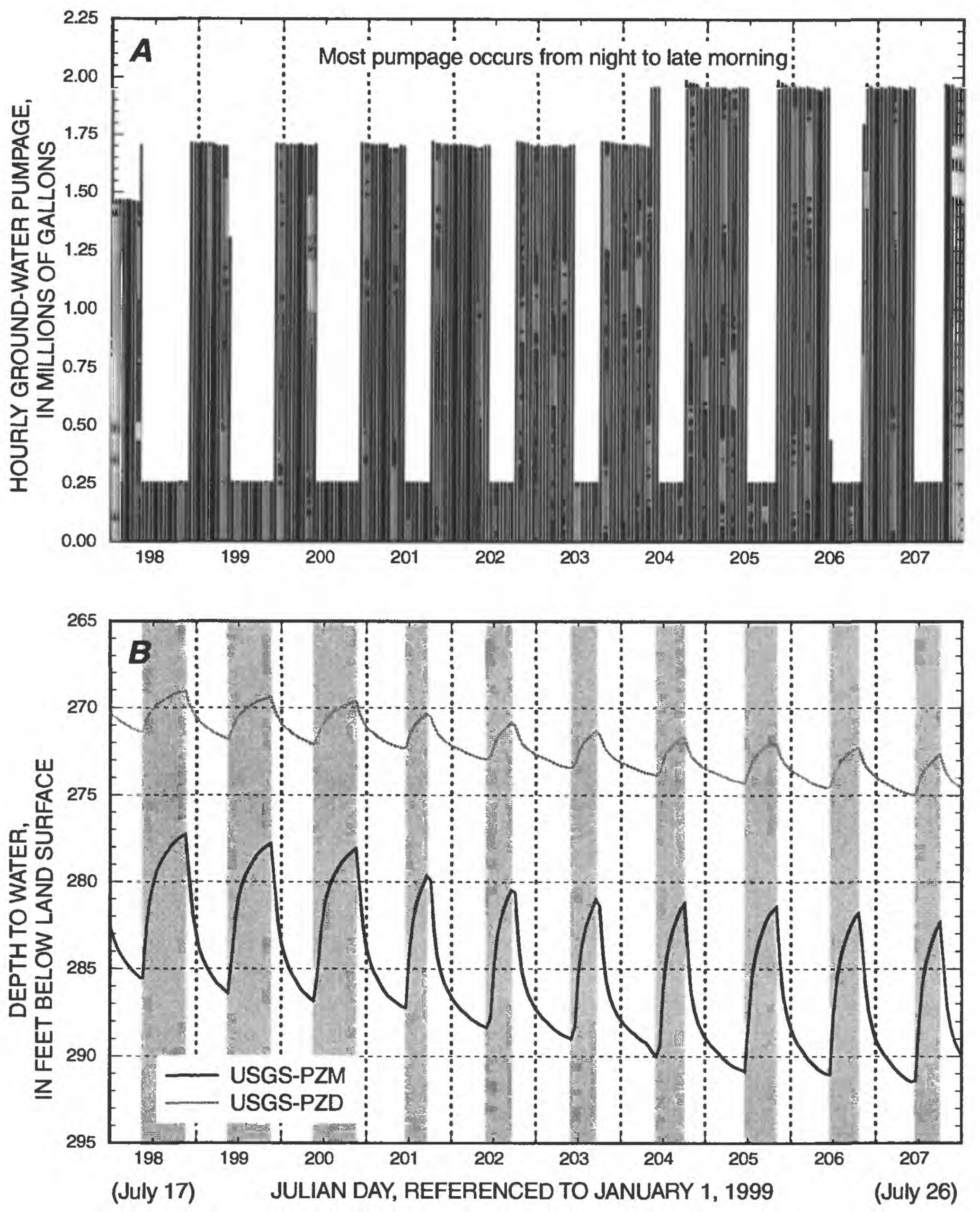

Figure 8. (A) Hourly ground-water pumpage from production wells near the Lorenzi site and (B) ground-water levels in piezometers USGS-PZM and -PZD, during a period of diurnal pumping, at the Lorenzi site, Las Vegas, Nevada, July 17-26, 1999. [Ground-water pumpage in (A) is from LVVWD wells $28,29,33,69,72,88,92,94$, $101,103,116$, and 117 , and shaded areas in $(B)$ are periods of decreased pumpage.] 
day when pumps are turned off (fig. $8 B$ ); daily waterlevel fluctuations in USGS-PZD were about $8 \mathrm{ft}$ during diurnal pumping seasons (fig. 11). Ground-water levels during the 1998-99 season of artificial recharge are shown in figures $12 \mathrm{~A}$ and 13 . During seasons of artificial recharge, water levels generally rise with a linear trend, except for periods when artificial recharge is reduced and water levels temporarily decline (fig. 12A). Water levels in USGS-PZD are usually the deepest of the three piezometers at the Lorenzi site, but become shallower than those in USGS-PZM after extended periods of artificial recharge (figs. $12 \mathrm{~A}$ and 13) and become deeper when artificial recharge is reduced (fig. 12A).

\section{AQUIFER-SYSTEM COMPACTION}

Aquifer-system compaction monitored by the borehole extensometer at the Lorenzi site is measured with a linear potentiometer, an analog chart recorder, and a dial gage. The linear potentiometer is the primary measuring device at the site. A linear potentiometer measures changes in distance and outputs the distance changes (compaction) as changes in millivolts. The potentiometer range of motion is $3.937 \mathrm{in}$. and compaction is reported to $1.0 \mathrm{in} . \times 10^{-4}$ in., which is within the resolution of the potentiometer. Potentiometer output is recorded every hour on an electronic data logger and retrieved periodically. Potentiometer output is converted from millivolts to compaction by applying a linear relation derived from calibration data. The reported potentiometer readings are not intended to represent the absolute accuracy of the aquifer-system compaction measurements because the potentiometer measurements are affected by the accuracy of the dial-gage measurements, which are used to calibrate the potentiometer. The analog chart recorder provides a continuous record of compaction data and ensures data are collected if the linear potentiometer or electronic data logger malfunctions. Readings from the dial gage are recorded manually during site visits and are used to evaluate potentiometer performance.

Aquifer-system compaction measured with the linear potentiometer during the period of record is shown in figure $6 \mathrm{~B}$. Compaction data are cumulatively measured relative to the first day of record (November $16,1994)$ and do not represent the total amount of compaction that has occurred at the Lorenzi site. Aquifersystem compaction is measured between a depth of
$12 \mathrm{ft}$ below land surface (bottom of the extensometer table legs) and $800 \mathrm{ft}$ below land surface (bottom of the extensometer borehole). The borehole extensometer at the Lorenzi site cannot measure total land subsidence because compressible sediments are below the depth of the extensometer borehole.

During the period of record, a maximum of 1.0327 in. of aquifer-system compaction was measured at the Lorenzi site (fig. $6 B$ ). The average annual net compaction, which equals total compaction minus total expansion, was about 0.2000 in. From 1994 to 1997 , aquifer-system expansion was minimal and the average annual net compaction was about 0.2370 in. From 1998 to 1999 , the period coinciding with increased artificial recharge and higher annual water levels, the average annual rate of compaction, including compaction and expansion, was about 0.1445 in. During the period of record, the average rate of compaction for a pumping season was about 0.2224 in. During the 1997-98 artificial-recharge season, about $0.0342 \mathrm{in}$. of aquifer-system expansion occurred and during the 1998-99 artificial-recharge season, about 0.0669 in. of aquifersystem expansion occurred. Aquifer-system compaction fluctuated seasonally in a manner similar to waterlevel fluctuations in the piezometers (fig. 6). The greatest rates of aquifer-system compaction correspond to periods of declining water levels in the piezometers and reduced rates of compaction, or aquifer-system expansion correspond to periods of rising water levels in the piezometers. During the 1994-95, 1995-96, and 1996-97 seasons of artificial recharge, residual compaction, which occurs when water-levels are not declining (Ireland and others, 1984), was measured (figs. 6 and 9).

Aquifer-system compaction during the 1995 season of near-continuous pumping is shown in figures $9 B$ and 10 and aquifer-system compaction for the 1999 season of diurnal pumping is shown in figures $7 C$ and 11. During seasons of near-continuous and diurnal pumping, aquifer-system compaction occurred at a relatively constant rate. When water levels temporarily rose by more than about $9 \mathrm{ft}$ during periods of reduced pumping, aquifer-system compaction rates decreased (fig. 7). Aquifer-system compaction during the 199899 season of artificial recharge is shown in figures $12 B$ and 13. During the 1995-96 and 1996-97 seasons of artificial recharge, aquifer-system compaction rates were less than during the intervening seasons of nearcontinuous pumping (fig. $6 B$ ). During the 1997-98 and 1998-99 seasons of artificial recharge, aquifer-system 

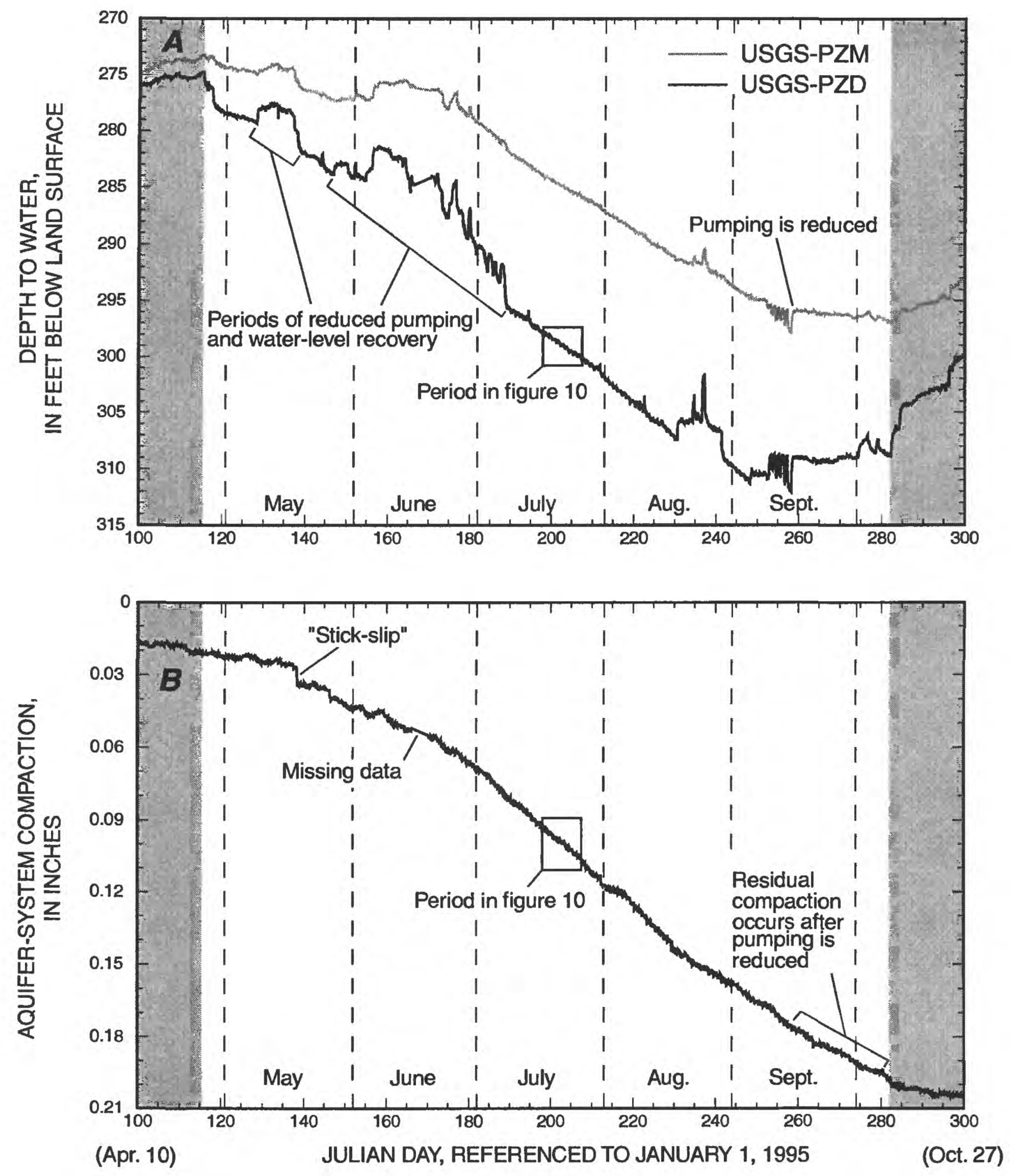

Figure 9. (A) Ground-water levels in piezometers USGS-PZM and -PZD and (B) aquifer-system compaction in extensometer USGS-EXT1, during a season of near-continuous pumping of nearby production wells, at the Lorenzi site, Las Vegas, Nevada, April 10-October 27, 1995. [Shaded areas are periods when the majority of LVVWD wells are not pumping.] 


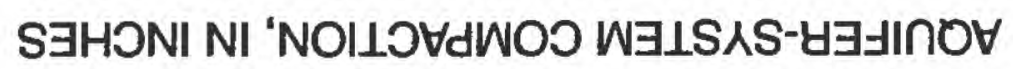

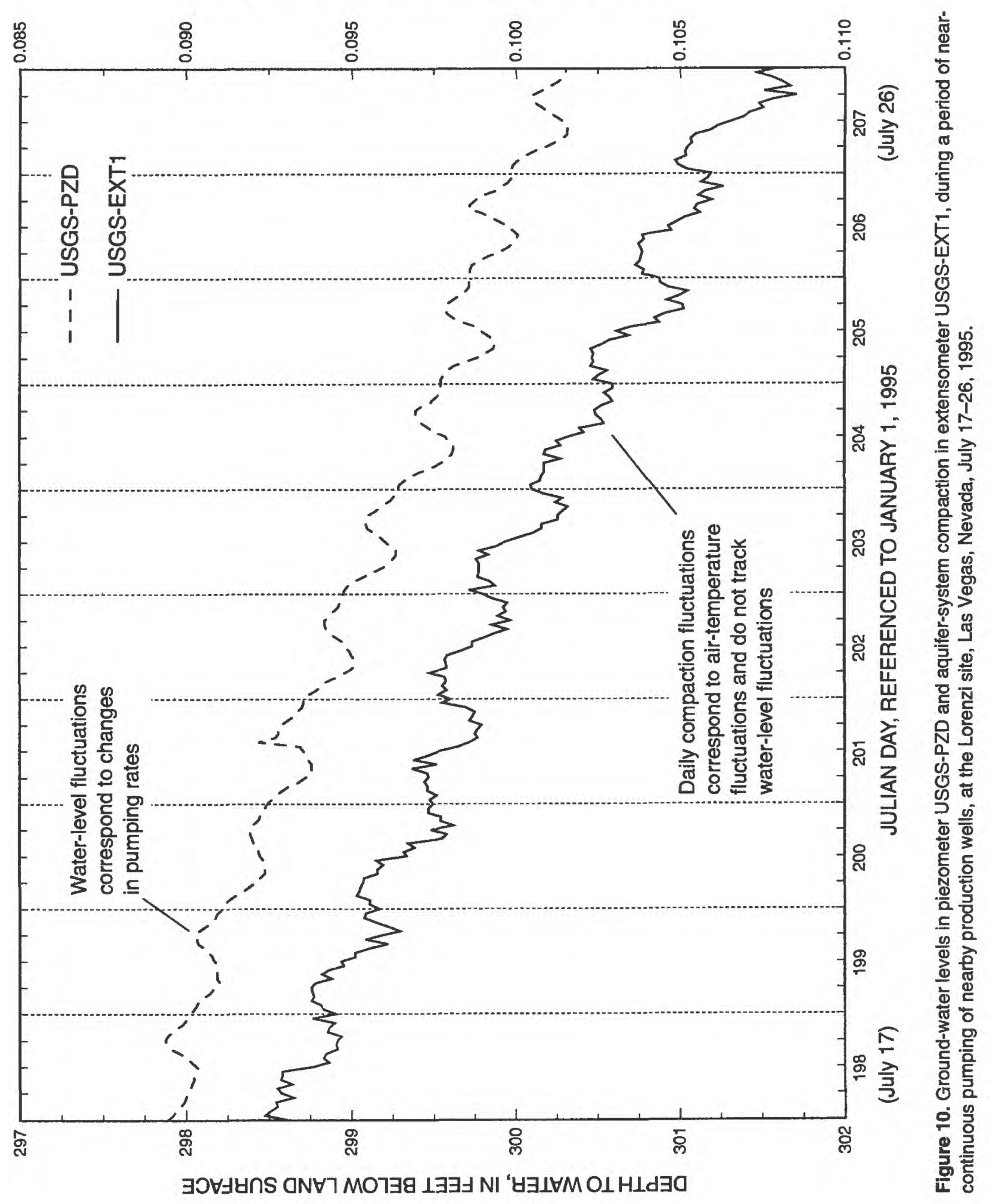








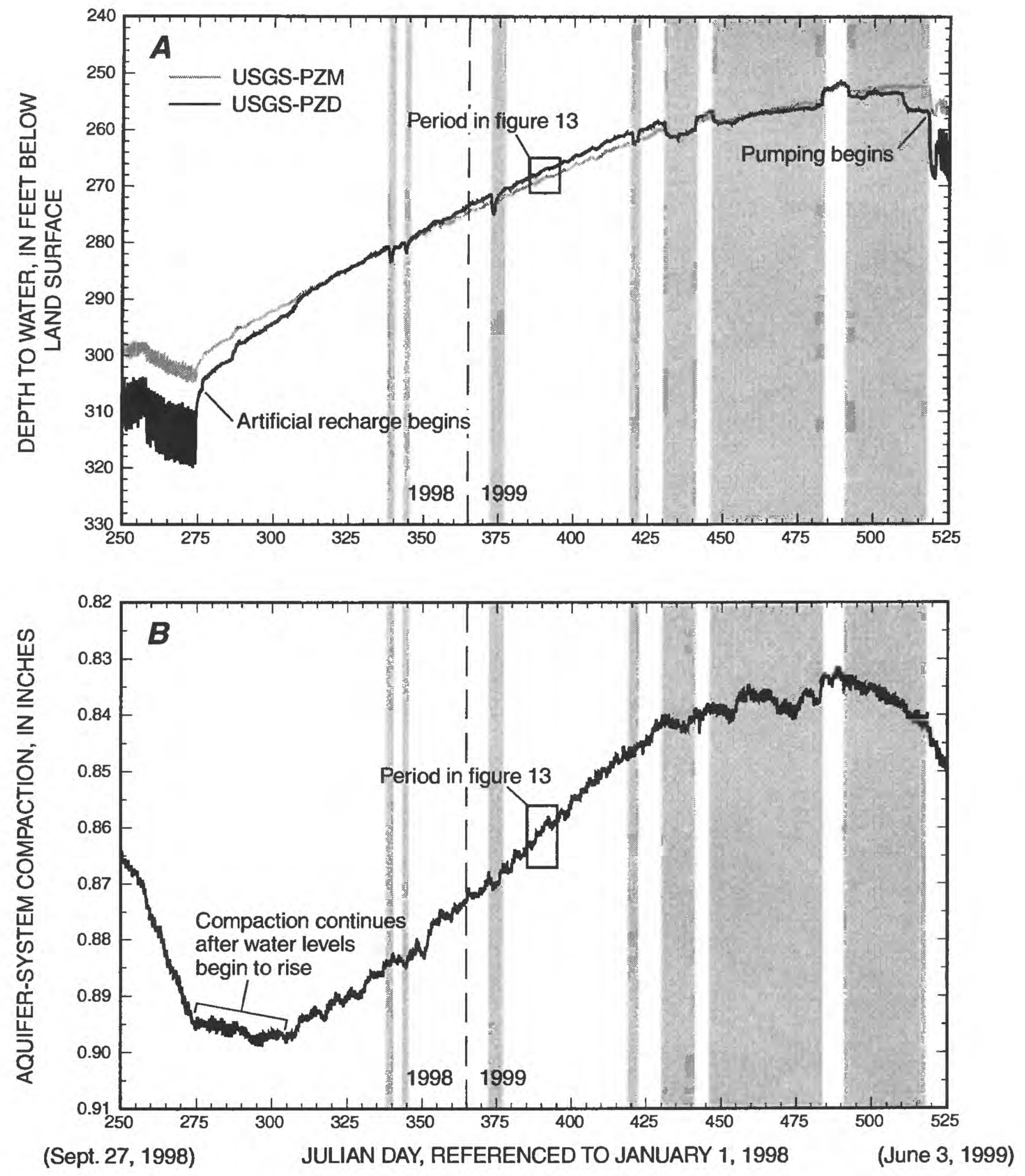

Flgure 12. (A) Ground-water levels in piezometers USGS-PZM and -PZD, and (B) aquifer-system compaction in extensometer USGS-EXT1, during a season of artificial recharge of nearby recharge wells, at the Lorenzi site, Las Vegas, Nevada, September 27, 1998-June 3, 1999. [Shaded areas are periods of reduced artificial recharge.] 


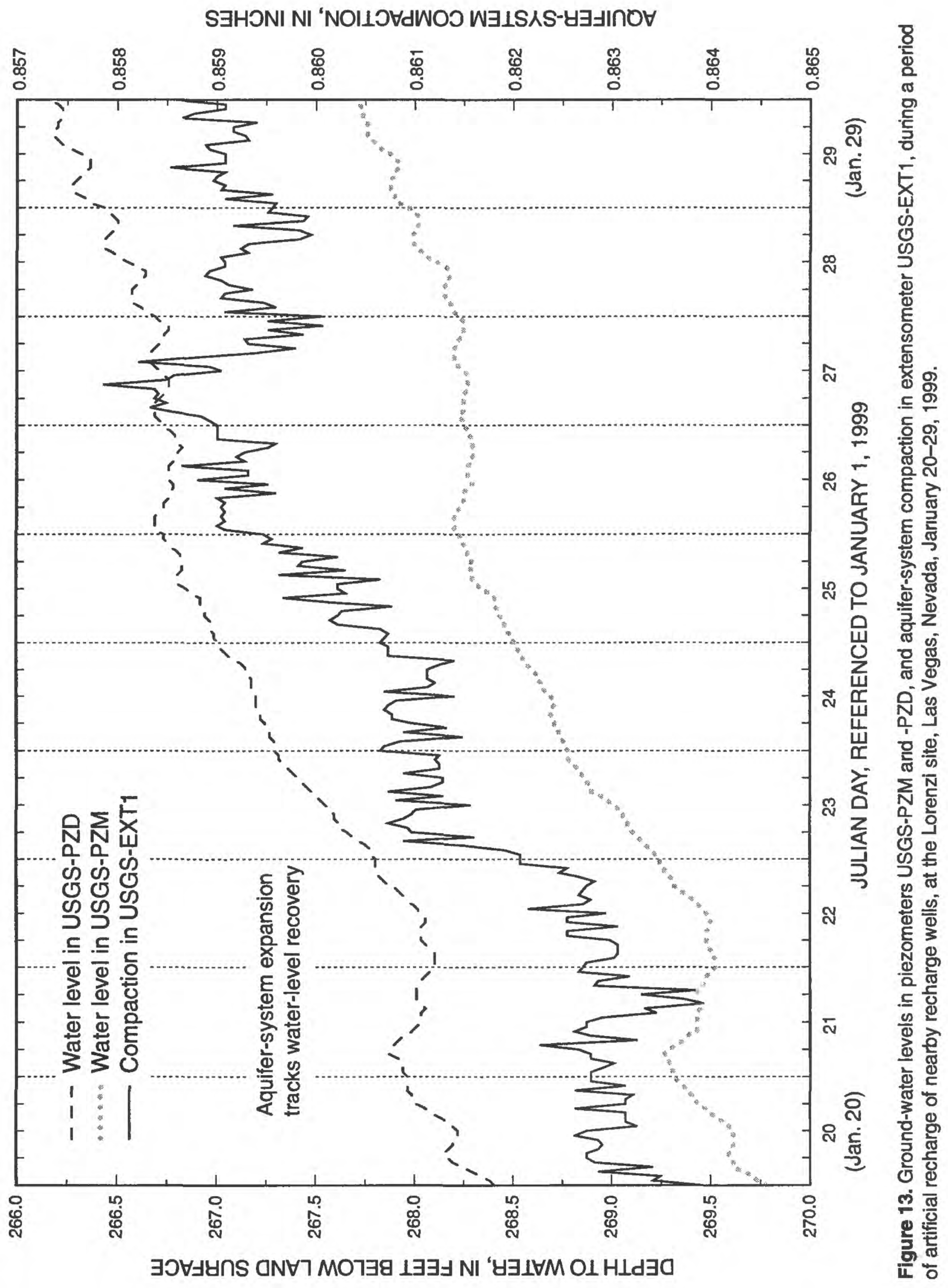


expansion occurred at a relatively constant rate, except for periods when artificial recharge was decreased and aquifer-system compaction occurred (figs. $6 B$ and $12 B)$.

Figure $9 B$ shows the effect of downhole frictional stresses on the extensometer record. The effect, sometimes referred to as "stick-slip," is revealed as a steplike shift in the compaction record and is caused by the instantaneous release of frictional stress that builds up at a point (or points) of contact between the extensometer pipe and the borehole casing (Riley, 1986). Stickslip is often associated with changes in aquifer-system stress associated with quickly declining water levels (F.S. Riley, U.S. Geological Survey, oral commun., 2000). In figure 9, about $3.5 \mathrm{ft}$ of water-level decline precedes the stick-slip.

Daily aquifer-system compaction fluctuations during seasons of pumping are contrary to seasonal trends: daily compaction corresponds to rising groundwater levels and daily expansion corresponds to declining ground-water levels (figs. 10 and 11). The magnitude of daily compaction fluctuations during periods of near-continuous pumping, when water-level fluctuations are relatively small, are about the same as daily compaction fluctuations during periods of diurnal pumping, when water-level fluctuations are relatively large (figs. 10 and 11). No daily compaction fluctuations are during cooler months, when daily temperatures do not fluctuate as much (fig. 13). Analyses of the extensometer shed-temperature data reveal that the periods of daily compaction associated with rising in ground-water levels correspond to periods of increasing shed temperature, which often exceed $120^{\circ} \mathrm{F}$ during summer days. Temperature fluctuations cause the metal components of an extensometer to expand and contract, and can cause the extensometer table to move relative to the extensometer pipe. The temperature induced motion can be detected by the linear potentiometer and recorded as compaction or expansion (D.L. Galloway, U.S. Geological Survey, oral commun., 1999). Barometric-pressure changes can cause air to move in to or out of the extensometer borehole. The moving air can affect the borehole air temperature and potentially cause the extensometer pipe to expand or contract, adversely affecting the extensometer record (Evans and Pool, 2000). However, analyses of barometric-pressure, borehole-air temperature, and extensometer data at the Lorenzi site indicate that barometric-pressure and borehole-air temperature fluctuations do not affect the extensometer data.

\section{SUMMARY}

During the period of record, water levels in piezometers at the Lorenzi site cyclically fluctuated in a manner consistent with alternating seasons of groundwater pumpage and artificial recharge in nearby production wells: declining water levels corresponded to periods of ground-water pumpage and rising water levels corresponded to periods of artificial recharge. Continual depth-to-water measurements ranged from 221.1 to $243.5 \mathrm{ft}$ below land surface in USGS-PZS, from 251.9 to $311.5 \mathrm{ft}$ below land surface in USGS-PZM, and from 251.5 to $328.8 \mathrm{ft}$ below land surface in USGS-PZD.

During the period of record, aquifer-system compaction rates at the Lorenzi site cyclically fluctuated in a manner similar to water levels in the piezometers. Periods of greatest compaction rates corresponded to declining water levels and periods of reduced compaction rates or aquifer-system expansion corresponded to periods of rising water levels. During the period of record, a maximum of 1.0327 in. of aquifer-system compaction was measured at the Lorenzi site. The average annual rate of compaction, including compaction and expansion, was about 0.2000 in. From 1994 to 1997, the average annual rate of compaction, including compaction and expansion, was about 0.2370 in. and from 1998 to 1999 , the average annual rate of compaction, including compaction and expansion, was about $0.1445 \mathrm{in}$. During the period of record, the average rate of compaction for a pumping season was about 0.2224 in. During the 1997-98 artificial-recharge season, about 0.0342 in. of aquifer-system expansion occurred and during the 1998-99 artificial-recharge season, about 0.0669 in. of aquifer-system expansion occurred.

\section{REFERENCES CITED}

Amelung, F., Galloway, D.L., Bell, J.W., Zebker, H.A., and Laczniak, R.J., 1999, Sensing the ups and downs of Las Vegas: InSAR reveals structural control of land subsidence and aquifer-system deformation: Geology, v. 27, no. 6, p. 483-486.

Bell, J.W., 1981, Subsidence in Las Vegas Valley: Nevada Bureau of Mines and Geology Bulletin 95, 84 p.

Bell, J.W., and Price, J.G., 1993, Subsidence in Las Vegas Valley, 1980-91-Final Project Report: Nevada Bureau of Mines and Geology Open-File Report 93-4, variable pagination. 
Carpenter, Everett, 1915, Ground water in southeastern Nevada: U.S. Geological Survey Water-Supply Paper $365,86 \mathrm{p}$.

Domenico, P.A., Mifflin, M.D., and Mindling, A.L., 1966, Geologic controls on land subsidence in Las Vegas Valley, in Proceedings, Fourth Annual Engineering Geologist and Soil Engineering Symposium: Moscow, Idaho, p. 113-121.

Domenico, P.A., Stephenson, D.A., and Maxey, G.B., 1964, Ground water in Las Vegas: Nevada Department of Conservation and Natural Resources, Water Resources Bulletin 29, 53 p.

Evans, D.W., and Pool, D.R., 2000, Aquifer Compaction and Ground-Water Levels in South-Central Arizona: U.S. Geological Survey Water-Resources Investigations Report 99-4249, 54 p.

Harrill, J.R., 1976, Pumping and ground-water storage depletion in Las Vegas Valley, Nevada, 1955-1974: Nevada Division of Water Resources, Water Resources Bulletin 44, $70 \mathrm{p}$.

Ireland, R.L., Poland, J.F., and Riley, F.S., 1984, Land subsidence in the San Joaquin Valley, California, as of 1980: U.S. Geological Survey Professional Paper 437-I, $93 \mathrm{p}$.

Malmberg, G.T., 1964, Land subsidence in Las Vegas Valley, Nevada, 1935-63: Nevada Department of Conservation and Natural Resources Water Resources Information Report 5, $10 \mathrm{p}$.

1965, Available water supply of the Las Vegas ground-water basin, Nevada: U.S. Geological Survey Water-Supply Paper 1780, 116 p., 13 pls.

Maxey, G.B., and Jameson, C.H., 1948, Geology and water resources of Las Vegas, Pahrump, and Indian Spring Valleys, Clark and Nye Counties, Nevada: Nevada State Engineer, Water Resources Bulletin 5, 121 p.

Mindling, A.L., 1965, An investigation of the relationship of the physical properties of fine-grained sediments to land subsidence in Las Vegas Valley, Nevada: University of Nevada, Reno, unpublished Master's Thesis, $90 \mathrm{p}$.
1971, A summary of data relating to land subsidence in Las Vegas Valley: University of Nevada, Desert Research Institute, $55 \mathrm{p}$.

Morgan, D.S., and Dettinger, M.D., 1996, Ground-water conditions in Las Vegas Valley, Clark County, Nevada, Part 2, Hydrogeology and simulation of ground-water flow: U.S. Geological Survey Water-Supply Paper 2320-B, 124 p.

Paillet, F.L., and Crowder, R.E., 1996, A generalized approach for the interpretation of geophysical well logs in ground-water studies-theory and application: Ground Water, v. 34 , no. 5 , p. $883-898$.

Pavelko, M.T., Wood, D.B., and Laczniak, R.J., 1999, Las Vegas Valley, Nevada - Urbanization: Gambling with water in the desert, in Galloway, D., Jones, D., and Ingebritsen, S., eds., Land subsidence in the United States: U.S. Geological Survey Circular 1182, p. 49-64.

Plume, R.W., 1989, Ground-water conditions in Las Vegas Valley, Clark County, Nevada, Part 1, Hydrogeologic framework: U.S. Geological Survey Water-Supply Paper 2320-A, 15 p.

Riley, F.S., 1986, Developments in borehole extensometry, in Johnson, A.I., Carbognin, L., and Ubertini, L., eds., Proceedings, Land Subsidence-Third International Symposium on Land Subsidence, Venice, Italy, March 1984: International Association of Hydrological Sciences Publication 151, p. 169-186.

Sneed, M., Pavelko, M.T., and Galloway, D.L., 2000, Modeling residual aquifer-system compaction: constraining the vertical hydraulic diffusivity of thick aquitards, in Proceedings of the Sixth International Symposium on Land Subsidence: Ravenna, Italy, September 24-29, 2000, International Association of Hydrological Sciences Publication, p. 343-355.

Waichler, S.R., and Cochran, G.F., 1993, Modeling and prediction of land subsidence in Las Vegas Valley, Nevada, in Bell, J.W., and Price, J.G., Subsidence in Las Vegas Valley, 1980-91 — Final Project Report: Nevada Bureau of Mines and Geology Open-File Report 93-4, variable pagination. 